\title{
OAK RIDGE
}

NATIONAL LABORATORY

\section{Review of Sorghum Production Practices: Applications for Bioenergy}

\section{June 2010}

Prepared by

Anthony F. Turhollow, Ph.D.

Erin G. Webb, Ph.D., P.E. Mark E. Downing, Ph.D.

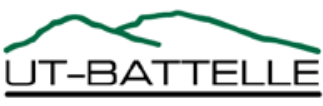




\title{
DOCUMENT AVAILABILITY
}

Reports produced after January 1, 1996, are generally available free via the U.S. Department of Energy (DOE) Information Bridge.

Web site http://www.osti.gov/bridge

Reports produced before January 1, 1996, may be purchased by members of the public from the following source.

\author{
National Technical Information Service \\ 5285 Port Royal Road \\ Springfield, VA 22161 \\ Telephone 703-605-6000 (1-800-553-6847) \\ TDD 703-487-4639 \\ Fax 703-605-6900 \\ E-mail info@ntis.gov \\ Web site http://www.ntis.gov/support/ordernowabout.htm
}

Reports are available to DOE employees, DOE contractors, Energy Technology Data Exchange (ETDE) representatives, and International Nuclear Information System (INIS) representatives from the following source.

Office of Scientific and Technical Information

P.O. Box 62

Oak Ridge, TN 37831

Telephone 865-576-8401

Fax 865-576-5728

E-mail reports@osti.gov

Web site http://www.osti.gov/contact.html

This report was prepared as an account of work sponsored by an agency of the United States Government. Neither the United States Government nor any agency thereof, nor any of their employees, makes any warranty, express or implied, or assumes any legal liability or responsibility for the accuracy, completeness, or usefulness of any information, apparatus, product, or process disclosed, or represents that its use would not infringe privately owned rights. Reference herein to any specific commercial product, process, or service by trade name, trademark, manufacturer, or otherwise, does not necessarily constitute or imply its endorsement, recommendation, or favoring by the United States Government or any agency thereof. The views and opinions of authors expressed herein do not necessarily state or reflect those of the United States Government or any agency thereof. 


\title{
Environmental Sciences Division
}

\section{Review of Sorghum Production Practices: Applications for Bioenergy}

\author{
Anthony F. Turhollow \\ Erin G. Webb \\ Mark E. Downing
}

Date Published: June 2010

Prepared by

OAK RIDGE NATIONAL LABORATORY

Oak Ridge, Tennessee 37831-6283

managed by

UT-BATTELLE, LLC

for the

U.S. DEPARTMENT OF ENERGY

under contract DE-AC05-00OR22725 



\section{CONTENTS}

Page

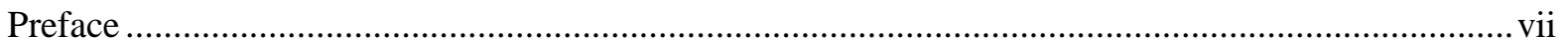

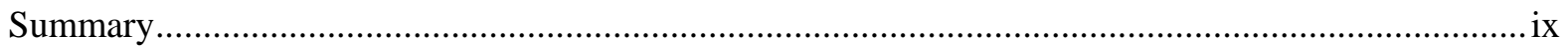

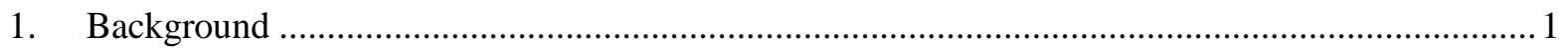

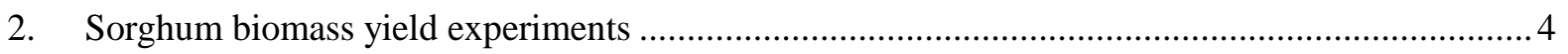

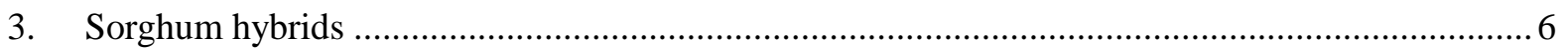

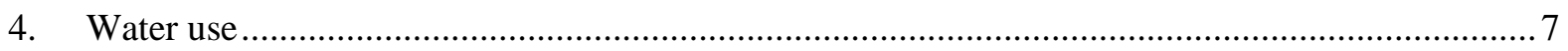

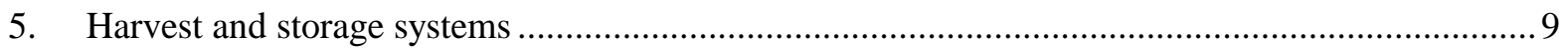

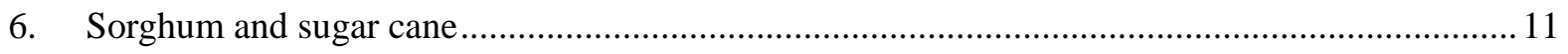

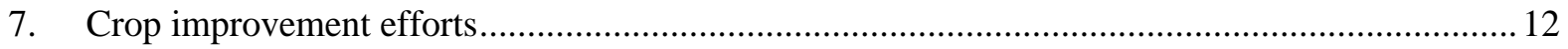

8. Adaptation of modern sorghum varieties and hybrids in developing countries ........................... 15

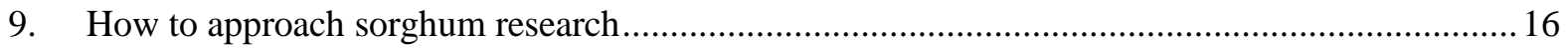

10. Why sorghum as an energy crop and needed improvements .............................................. 17

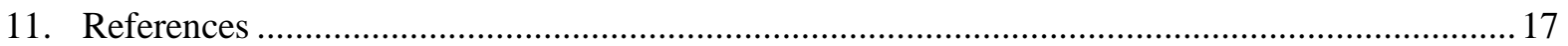





\section{LIST OF TABLES}

Table

Page

1. Sorghum types grown in the US and typical purposes and bioenergy applications for each............... 2

2. Forage sorghum, sorghum x sudangrass, and sudangrass characteristics based on Virginia, USA

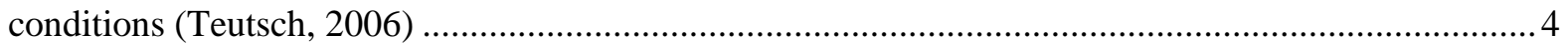

3. Sorghum yields and lodging in Indiana, USA in 1990 (Johnson et al, 1991) ................................. 5

4. Sorghum yields in Indiana, USA in 1989 (Cherney et al, 1990).................................................... 5

5. Sorghum double cropped with winter rye for four years in Indiana, USA had declining yield ${ }^{\mathrm{a}}$ over

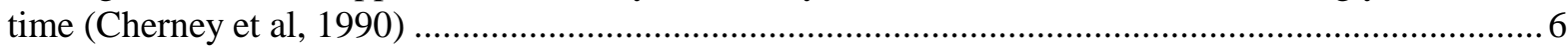

6. Biomass production, evapotranspiration, and water use efficiency for corn, sorghum, and millet in Northern India in 1979 and 1980 (Singh and Singh, 1995) ......................................................... 7

7. Yields, harvest index, and irrigation water use efficiency (WUE) for maize and sorghum at Zaragoza, Spain in 1995 (Farré and Faci, 2004) ............................................................................ 8

8. Dryland sorghum and winter wheat yields (Mg ha-1) in continuous and fallow rotations 1973-1987

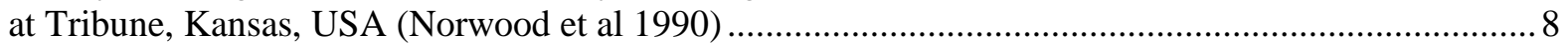

9. How sweet sorghum sugar content is affected by delay in crushing (Reddy et al, 2008)................ 10

10. How harvest timing (days after planting) affect sorghum yield and total ethanol from sorghum in

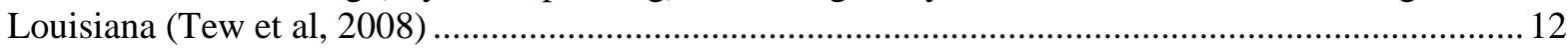

11. Hybrids relative to variety in India (Reddy et al; 2007, 2008) ................................................ 14

12. How rankings for sugar and grain change between rainy and nonrainy season over 2 years (Reddy

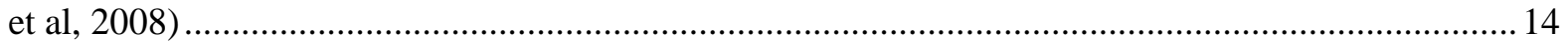





\section{PREFACE}

The following exhaustive literature review of sorghum production practices was developed by researchers at Oak Ridge National Laboratory to document the current state of knowledge regarding sorghum production and, based on this, suggest areas of research needed to develop sorghum as a commercial bioenergy feedstock. This work began as part of the China Biofuels Project sponsored by the DOE Energy Efficiency and Renewable Energy Program to communicate technical information regarding bioenergy feedstocks to government and industry partners in China, but will be utilized in a variety of programs in which evaluation of sorghum for bioenergy is needed. This report can also be used as a basis for data (yield, water use, etc.) for US and international bioenergy feedstock supply modeling efforts. 



\section{SUMMARY}

Sorghum has great potential as an annual energy crop. While primarily grown for its grain, sorghum can also be grown for animal feed and sugar. Sorghum is morphologically diverse, with grain sorghum being of relatively short stature and grown for grain, while forage and sweet sorghums are tall and grown primarily for their biomass. Under water-limited conditions sorghum is reliably more productive than corn. While a relatively minor crop in the United States (about 2\% of planted cropland), sorghum is important in Africa and parts of Asia. While sorghum is a relatively efficient user of water, it biomass potential is limited by available moisture.

As a cellulosic feedstock for bioenergy, the sweet and forage types are of interest. Energy sorghum is forage sorghum bred for high biomass production. Dual purpose forage, sweet, and energy sorghums produce both biomass and grain. Related sorghums, sudangrass and sorghum x sudangrass, may also have a role as short growing season crops or crops allowing two cuttings in one growing season. At present about $1 \times 10^{9} \mathrm{~L}$ of ethanol are produced from grain sorghum in the United States. There is a small production of energy from sweet sorghums.

Grain sorghums have been bred for dwarf stature and stand 0.6-1.2 m (2-4') tall. The maximum potential biomass yield of the grain sorghum type is about 23 dry $\mathrm{Mg} \mathrm{ha}^{-1}$. In an FAO document (from the mid 1990s) on sorghum in China, grain sorghum water requirements are stated as 350 to $700 \mathrm{~mm}$, depending on the length of the growing cycle (short-growth variety 90 days to long-growth variety 130 days). For optimum yields on good soil, short-growth, average-growth, and long growth varieties requires 500 to 600 (20 to 24), 650 to 800 (26 to 31), and 950 to 1100 (37 to 43) mm (inches) of well distributed rainfall, respectively (Natural Resources Institute, no date).

Sweet and forage sorghums have high yield potential, 20 to 40 dry $\mathrm{Mg} \mathrm{ha}^{-1}$. As an annual (instead of a perennial) crop, sorghum can be rotated with other annuals such as corn and soybeans or grown in multiple crop rotations, which can diversify production (reducing risk), improve soils and reduce weed and insect control requirements, making sorghum attractive to farmers (e.g. see Ngouajio, no date). In its breeding program for energy sorghum, Texas A\&M University has a yield goal of 45 dry $\mathrm{Mg} \mathrm{ha}^{-1}$ (20 dry tons acre ${ }^{-1}$ ) (Schill, 2007). Reddy (2008) indicates that sweet sorghum is similar to grain sorghum, but requires $700+\mathrm{mm}$ of rainfall. Because both sweet and forage sorghums are thick stemmed, they are typically $60 \%$ to $70 \%$ moisture (wet basis) at harvest and handled as a silage crop, rather than as a hay crop. Sweet sorghum can have sugar contents similar to sugar cane and, like sugar cane, it must be processed quickly to avoid losses of sugars. It may be possible to field dry forage sorghum to lower moisture content if utilized for energy purposes, rather than as a forage crop where feed quality is important. If the desired storage method is ensiling and the moisture content is too low, it is difficult to store the crop as silage. Lower moisture content can lower transport costs.

Sorghum planting strategies are largely determined by site conditions (e.g. available moisture, length of growing season), requirements of the preceding and succeeding crop, and objective(s) in growing sorghum [whether solely for grain, solely for biomass (and sugar), or for both grain and biomass (and sugar)]. Forage sorghums have higher growing temperature requirements than corn (Roth, 1995). Minimum temperature for forage sorghum growth is about $15^{\circ} \mathrm{C}\left(60^{\circ} \mathrm{F}\right)$ and optimum growth occurs when mean temperatures are between $24^{\circ} \mathrm{C}\left(75^{\circ} \mathrm{F}\right)$ and $27^{\circ} \mathrm{C}\left(80^{\circ} \mathrm{F}\right)$. Planting should occur when soil temperatures have reached $18^{\circ} \mathrm{C}\left(65^{\circ} \mathrm{F}\right)$ at 5.1 - to 10.2 -cm (2- to 4-inch) depth.

There are both photoperiod sensitive and photoperiod insensitive sorghums. Photoperiod insensitive sorghums initiate reproductive growth after a set amount of time regardless of day length. Grain sorghum has been bred in temperate climates to do this. Photoperiod sensitive sorghum begins 
reproductive growth (i.e. flowering) when day length reaches a certain threshold. This threshold depends on the particular genotype and ranges from 11.5 to 13.5 hours. If biomass is the desired product, sorghums with a photoperiod shorter than day length at the end of the growing season (first frost in temperate climates) allows the crop to maximize biomass production. However, disease and drought may limit how much of the growing season can be utilized and affect the timing of planting. In areas with longer growing seasons, it may be possible to grow a ratoon crop of sorghum (i.e. sorghum is harvested and then a second crop grows back from the roots). If a ratoon crop is desired, then sorghum with a longer photoperiod or photoperiod insensitive would be selected. Photoperiod sensitive sorghums generally do not set seed under Midwestern, USA conditions. Sorghums should be selected for an appropriate photoperiod for the region where they are grown, when they are planted, and the goal for which they are grown (biomass versus biomass plus grain).

Research at Purdue University (Cherney et al 1990, Johnson et al 1991) found that lodging resistance is critical for top yields. While two cuttings can reduce lodging, yield was greatly reduced. [Lodging is when plants fall over.] Varietal selection and agronomic practices may reduce lodging. Taller plants do not necessarily produce higher yields. Sorghum grown in monoculture had declining yields over time. Rye double cropped with sorghum can be a high yielding system.

Hybrids have a long history of use in sorghum production. Properly selected sorghum hybrids can help growers increase yields, use less water, reduce lodging losses, increase feed quality, and manage maturation (Bean et al 2004, Reddy et al 2008). Owens (2009) reported 20\% higher biomass yield from sorghum hybrids in trial conducted in the United States in 2008. Hybrid energy sorghums are available from at least two American seed companies, Ceres and Edenspace, and research could further enhance traits desired for bioenergy.

There are approximately 168,000 sorghum accessions held at repositories around the world, with the two largest repositories being ICRISAT and USDA. The sorghum genome is the second major cereal crop to be sequenced. China has significant sorghum genetic resources and has exported germplasm to other countries. Many Chinese sorghum varieties are tall and offer a wide range in days to maturity (80 to 190 days). Stresses screened for include drought, cold, saline and alkali soils, and various diseases (e.g. head smut) and pests (e.g. sugar cane aphid and European corn borer). Cold tolerance is an important trait available in Chinese germplasm. For biomass, ICRISAT focuses on sweet sorghum with significant grain yield. In the United States Texas A\&M focuses on high-yielding energy sorghum (i.e. for biomass and not grain). There are also brown midrib (BMR) sorghums that are lower in lignin. BMR sorghum was developed to improve feed quality (higher digestibility) and may also offer better characteristics than typical sorghum for bioconversion to ethanol.

One of the major challenges facing biomass crops, including sorghum, is logistics (harvest, transport, storage). Grain sorghum is harvested using equipment and systems common to other small grains, such as wheat. The logistics of grain sorghum (harvest, transport, storage) are well developed and similar to maize grain. Tall sorghums (forage, sweet, energy) are harvested with a forage or sugar cane harvester. High tonnages may require large self-propelled harvesters, which have a high capital cost. In areas where field and/or road conditions (combined with economics) limit the use of large-scale harvest equipment, smaller tractor-pulled forage harvesters are used (Pari et al, 2008). For costeffective harvesting it is advantageous to have an extended harvest season or, in the case of an area also growing sugar cane, to have the sorghum harvest season from the sugar cane harvest season and be able to utilize sugar cane harvesters that would otherwise be idle.

Moisture content presents a challenge for utilizing forage, sweet, and energy sorghums. Generally, these sorghums are thick-stemmed and high in moisture content at harvest (60\% to $70 \%$ on a wet 
basis), requiring either ensiling, or a cost-effective means of reducing moisture content below the point that permits dry storage methods (generally below 20\%), or quick processing. The cost of biomass transport generally increases with moisture content since the amount of dry biomass carried by a given container (or truck) is reduced by the weight of embedded water. If the sorghum could be reduced to a moisture content of $40 \%$, then the load could be increased, and costs may be reduced $40 \%$ under United States conditions. Road characteristics and local transport regulations limit the size and weight of transport equipment, but generally costs will be reduced as bulk load density and volume are increased to reach these limits.

Drying options and harvest logistics depend on use and storage plans. Due to the moisture content, sorghum for feed is generally handled as a silage crop (as opposed to a hay crop). To store the crop as silage (for feed), moisture content must be above $50 \%$. And while sweet sorghum can produce sugar contents rivaling sugarcane, the sugars must be processed quickly (like sugarcane). Forage sorghum used exclusively for energy could be allowed to dry in the field, but field drying can compromise sorghum's value for feed, reducing marketing options.

The option of rapid, intermediate processing could involve small scale pyrolysis, pelletization or cubing, but any of these would demand significant drying (optimally, to a moisture content of about 10\%). Pyrolysis would produce a liquid that might be more economically stored and transported.

Developing sorghum as an energy crop will need to be supported by an integrative research strategy that considers an entire cropping system (where sorghum may be one component) to sustainably and economically produce food, feed, fiber and fuels. Preliminary research questions that need to be explored include:

What sorghum products are desired?

- Both biomass (lignocellulose alone or lignocellulose and sugar) and grain?

- Primarily biomass (and grain produced, if any, is incidental)?

- Sugars (and possibly grain) with the bagasse as a secondary product?

What land will be used?

- Will sorghum replace current food and feed crops, or pasture?

- Will sorghum be integrated in crop rotations (potentially increasing long-term productivity of other crops)?

- Will sorghum be part of an expansion into marginal lands or part of recuperation of abandoned and degraded lands?

In addition to land use and product mix, productivity depends on intensity of production and constraining factors such as water. The feasibility of bioenergy from sorghum will depend on costs of required inputs, efficiency of operations, markets and prices for cropping system outputs and technologies available. For example, with today's conversion technologies, sweet sorghum for conventional ethanol may be the most viable bioenergy option, but in the future, lignocellulosic conversion technology may favor sorghum varieties with higher biomass yields per unit of input than sweet sorghum.

A question to research is whether one is better off utilizing sorghum that is specialized (e.g. energy sorghum for biomass and grain sorghum for grain) or sorghum that is multipurpose (e.g. sweet 
sorghum that produces both grain and biomass) instead? For example, if grain sorghum is grown on 1 unit of land and energy sorghum on 1 unit of land, will this produce more grain and biomass than dual purpose sorghum (a sorghum developed for both grain and biomass) grown on 2 units of land? The answer is likely to vary be location.

Storage is an issue with any bioenergy crop, particularly those with relatively short harvest seasons. To operate a conversion facility year round requires significant storage or diversification of feedstocks (e.g. woody crops, winter crops) to allow continuous harvest and delivery throughout the year. One means of reducing storage requirements is to extend the sorghum harvest season by staggering planting times, using varieties with differing maturities, and utilizing ratoon (multiple cutting) management.

Among potential annual bioenergy crops, sorghum may be advantageous where drought tolerance is important and it can enhance production of other crops (e.g. as seasonal cover crop or in rotations). Sorghum allows farmers flexibility in choice of crop from year to year. It has the potential for high yield (40+ dry $\left.\mathrm{Mg} \mathrm{ha}^{-1} \mathrm{yr}^{-1}\right)$. Genetic mapping combined with a relatively fast breeding and field testing cycle facilitate further improvements for bioenergy once desired feedstock characteristics and site requirements are clearly defined. Acknowledging that improvements for bioenergy could potentially diverge from those for feed and food, the following research agenda is proposed:

1) Define traits important for bioenergy and characterize sorghum collections for these traits

2) Develop cost-effective means to stabilize sweet sorghum juice so it does not need immediate processing

3) Increase sugar yields of sweet sorghum for use in the near term as an ethanol feedstock (or to supplement sugar from sugarcane)

4) Increase grain yields for sweet and energy sorghums to explore multi-product potential

5) Develop varieties for high biomass yields (energy sorghum)

6) High and low lignin varieties (high lignin for thermochemical conversion such as gasification or pyrolysis and low lignin for ethanol feedstock)

7) Research cropping systems including

- double cropping where sorghum supplements other grain production to increase overall output while reducing environmental impacts

- cover crop and inter-crop sorghum that helps control weeds and pests for high-value crops (vegetables) while improving soils

While perennial biomass crops may be preferred for environmental benefits, annuals such as sorghum provide farmers with more agility to shift crop production in response to market signals. Both perennials and annuals can play important roles in an integrated system designed to minimize input requirements and maximize production of multiple food, feed, fiber and fuel products. 



\section{BACKGROUND}

Sorghum [Sorghum bicolor (L.) Moench] has much potential as an annual energy crop. It is morphologically diverse, with grain sorghum being of relatively short stature and grown for grain, while forage/sweet sorghums are tall and grown primarily for their biomass. Sorghum is a more efficient user of water than corn under water-limited conditions and is well adapted to environments where water availability is a constraint.

Different sorghum types can be used as bioenergy feedstocks for a variety of conversion technologies (see Table 1). Sorghum grain can be utilized alongside corn grain in starch-to-ethanol facilities. In 2008 , about $2.5 \times 10^{6} \mathrm{Mg}\left(100 \times 10^{6}\right.$ bushels $)$ of grain sorghum was used to produce about $1.0 \times 10^{9} \mathrm{~L}$ (270 $\times 10^{6}$ gallons) of ethanol in the United States. There is growing interest in using sweet sorghum juice to produce ethanol. For example, in 2008 Renergie, Inc. received a \$1.5 million grant from the state of Florida to design and construct a facility to produce ethanol from sweet sorghum juice (News.mongabay.com, 2008). In India, in Andhra Pradesh State, Runsi Distilleries has a sweet sorghum to ethanol facility, and Tata Chemicals is, or has recently finished, constructing a sweet sorghum to ethanol facility in Maharashtra state (FBAE, 2008; Alibaba.com, 2008). In 2008, it was announced that Nigeria Global Biofuels would construct a $1.5 \times 10^{6} \mathrm{~L}$ per day ethanol facility (D-8 Secretariat, 2008) in Ondo State. According to the National Sorghum Producers, sweet sorghum is currently being used in India, South America, and the Philippines to produce ethanol (National Sorghum Producers, no date). Sweet sorghum juice is also of interest for on-farm ethanol production (Bennett and Anex, 2008).

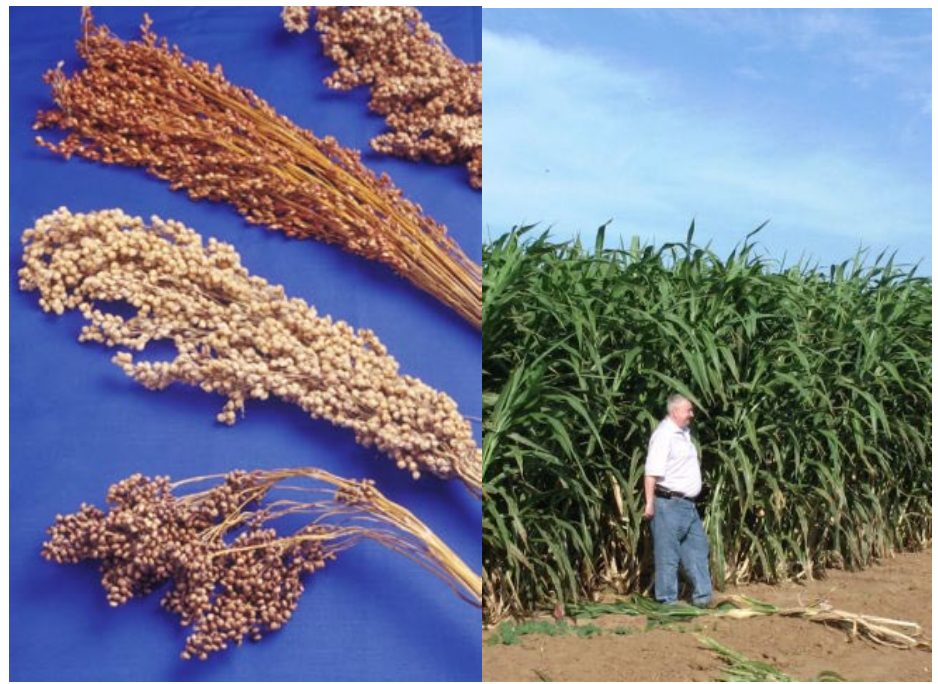

Figure 1. Sorghum types and bioenergy applications: sorghum grain (left, photo courtesy of USDA ARS) can be utilized much like corn grain in starch-to-ethanol facilities while the biomass of forage, or energy, sorghum (right, photo courtesy of Dave Jordan, MacDon Industries, LLC) can be harvested as a cellulosic feedstock.

As a cellulosic feedstock, the sweet and forage types are of interest. Energy sorghum is forage sorghum bred for high biomass production. Dual purpose forage and energy sorghums produce both biomass and grain, and multipurpose sweet sorghums can produce biomass, sugar, and grain. Related sorghums, sudangrass, and sorghum x sudangrass may also have a role as short growing season crops or crops allowing two cuttings in one growing season. 
Table 1. Sorghum types, conventional uses, and bioenergy applications for each

\begin{tabular}{|l|l|l|}
\hline Sorghum type & Typical Purposes in US & Applications for Bioenergy and Some Current Examples \\
\hline Grain sorghum & Grain harvested for livestock feed & $\begin{array}{l}\text { Grain can be used in starch to ethanol conversion processes } \\
\text { In 2008, 2.5x 106 Mg of grain sorghum used to produce } \\
\text { about 1.0x109 L of ethanol in US } \\
\text { Sorghum residue (stubble) can be used as feedstock for } \\
\text { cellulosic ethanol conversion }\end{array}$ \\
\hline Sweet sorghum & $\begin{array}{l}\text { High-sugar content sorghum } \\
\text { varieties - sugar harvested for } \\
\text { molasses and/or biomass used as } \\
\text { livestock feed }\end{array}$ & $\begin{array}{l}\text { Sweet sorghum juice fermented to produce ethanol; on- } \\
\text { farm conversion processes currently being explored } \\
\text { In 2008, Renergie, Inc. received a grant from state of } \\
\text { Florida to design and construct facility to produce ethanol } \\
\text { from sweet sorghum juice }\end{array}$ \\
& $\begin{array}{l}\text { In India, two sweet sorghum to ethanol facilities have been } \\
\text { publicized by Runsi Distilleries and Tata Chemicals }\end{array}$ \\
\hline Forage sorghum & Biomass harvested for livestock feed & $\begin{array}{l}\text { Good candidate as annual crop for cellulosic ethanol } \\
\text { conversion processes; forage sorghums being bred for high } \\
\text { biomass yield for bioenergy applications }\end{array}$ \\
& $\begin{array}{l}\text { DOE Regional Feedstock Partnership is currently } \\
\text { conducting energy sorghum field trials in Iowa, Kansas, } \\
\text { Kentucky, Mississippi, and North Carolina }\end{array}$ \\
\hline
\end{tabular}

Sorghums are thought to originate just north of the equator in Africa (in what today are Chad, Ethiopia, and Sudan). They are sensitive to day length or photoperiod and need consistent day length of up to 12 hours to trigger an internal mechanism to initiate reproductive growth, first flowers and later seeds. Sorghums have also long been cultivated in China, with records possibly dating back to the $3^{\text {rd }}$ century A.D., and over time many landraces and varieties developed or were bred (Qingshan and Dahlberg, 2001).

In 2004, 59\% of the land producing sorghum was in Africa, 25\% in Asia, and 11\% in North and Central America. In terms of production (tons produced), contributions were Asia 45\%, Africa 25\%, and North and Central America 21\% (ICRISAT, 2009). Productivity in Africa and average productivity in Asia are held down by many factors: lack of improved seeds and technology, lack of markets and capital, and primarily the fact that most farmers are poor, lack irrigation, and use marginal rain fed lands where their best strategy is to reduce risk with low seeding rates and zero (or minimal) investment in other inputs (fertilizer, weed and pest control). In Asia, sorghum yields are lower in India, Pakistan, and Yemen. In China, average sorghum yield is around $4 \mathrm{Mg} \mathrm{ha}^{-1}$, similar to yield observed in the United States.

Grain sorghums have been bred for dwarf stature and stand 0.6-1.2 m (2-4 ft) tall. In 2008, average grain sorghum yield in the United States was 3.51 dry $\mathrm{Mg} \mathrm{ha}^{-1}$ (assuming 86\% dry matter) (65.0 bu $\mathrm{acre}^{-1}$ ). Assuming a grain:residue ratio of 1:1, $3.51 \mathrm{dry} \mathrm{Mg} \mathrm{ha}^{-1}$ of residue was produced. Grain sorghum types will not be high yielding biomass crops. Under irrigation in California, yield was 6.59 $\mathrm{Mg} \mathrm{ha}^{-1}$ (105 bu acre ${ }^{-1}$ ) in 2006 for a total of biomass yield of 11.3 dry $\mathrm{Mg} \mathrm{ha}^{-1}$ (assuming a 1:1 grain:residue ratio and $86 \%$ dry matter grain). The maximum yield of grain sorghum in 2009 in the Yield and Management Contest by the National Sorghum Producers was $13.6 \mathrm{Mg} \mathrm{ha}^{-1}$ (216 bu acre ${ }^{-1}$ ) irrigated and $12.4 \mathrm{Mg} \mathrm{ha}^{-1}$ (197 bu acre ${ }^{-1}$ ) rain fed, which would give total biomass yields of 23 and 21 dry $\mathrm{Mg} \mathrm{ha}^{-1}$ (assuming 86\% grain dry matter and grain:residue ratio of 1:1) (National Sorghum Producers 2009). Based on the results of the National Sorghum Producers Yield and Management Content, the current maximum potential biomass yield of the grain sorghum type is about 23 dry $\mathrm{Mg}$ $\mathrm{ha}^{-1}$. 
Sweet and forage sorghums have higher biomass yield potential (20 to 40 dry $\mathrm{Mg} \mathrm{ha}^{-1}$ ) than grain types. They are attractive to farmers as they can be grown as an annual (instead of a perennial) crop and be rotated with other annuals such as corn and soybeans. Sorghums for energy can also be grown as an annual energy crop alongside perennial crops to respond to quick shifting feedstock markets. Reddy (2008) indicates that sweet sorghum is similar to grain sorghum, but requires $700+\mathrm{mm}$ of rainfall. Because both sweet and forage sorghums are thick stemmed, the moisture contents at harvest are typically $60-70 \%$ (wet basis) and are generally handled as a silage crop rather than as a hay crop. Sweet sorghum can have sugar contents similar to sugar cane and like sugar cane requires quick processing to utilize the sugars and avoid degradation. It may be possible to field dry forage sorghum to lower moisture contents if utilized for energy purposes rather than as a forage crop where feed quality is important. If the desired storage method is ensiling and the moisture content is too low (below $50 \%$ on a wet basis), it is difficult to store the crop as silage. Reducing moisture content and handling as a dry crop $(<20 \%)$ is desirable to reduce transportation and storage costs.

Forage sorghums have higher growing temperature requirements than corn (Roth, 1995). Minimum temperature for forage sorghum growth is about $15^{\circ} \mathrm{C}\left(60^{\circ} \mathrm{F}\right)$ and optimum growth occurs when mean temperatures are between $24^{\circ} \mathrm{C}\left(75^{\circ} \mathrm{F}\right)$ and $27^{\circ} \mathrm{C}\left(80^{\circ} \mathrm{F}\right)$. Planting should occur when soil temperatures have reached $18^{\circ} \mathrm{C}\left(65^{\circ} \mathrm{F}\right)$ at 5.1- to $10.2-\mathrm{cm}$ (2- to 4-inch) depth. In Pennsylvania, Roth (1995) recommends a planting depth of 1.9 to $3.2 \mathrm{~cm}$ (0.75 to 1.25 inches). In Virginia, Teutsch (2006) recommends 2.5 to $3.8 \mathrm{~cm}$ (1.0 to 1.5 inches) (Table 1$)$. The recommended planting depth for sorghum $\mathrm{x}$ sudangrass and sudangrass is shallower. Planting rates of 9 to $13 \mathrm{~kg} \mathrm{ha}^{-1}$ (8 to $12 \mathrm{lb} \mathrm{acre}^{-1}$ ) with $75 \%$ emergence results in plant populations of about 210,000 to 370,000 plants ha ${ }^{-1}$ (85,000 to 150,000 plants acre ${ }^{-1}$ ). Excessive seeding rates can lead to lodging problems (Roth, 1995). [Lodging is when plants fall over. Lodged crops are difficult to mechanically harvest.] Planting too early and too deep are common reasons for poor sorghum stands (Teutsch, 2006). For its high biomass sorghum, Ceres (2009) recommends 185,000, 245,000, and 295,000 seeds ha ${ }^{-1}(75,000,100,000$, and 120,000 seeds acre $^{-1}$ ) for marginal nonirrigated, good nonirrigated, and irrigated land, respectively.

Yield can be affected by harvest timing, fertilization, and irrigation. Bolsen (2002) reviewed studies of the effect of maturity on yield of grain (his Table 1) and forage sorghums (his Table 2). He found that for the grain sorghum, total dry matter increased from the late milk to the late dough stage, but decreased from the late-dough to the hard-grain stage because leaf senescence and broken heads or stalks disconnected from the upper portion of the stalk caused whole-plant dry matter yields to decrease to the point where it was not greater (i.e. statistically significantly different) at the hard-grain stage than at the late-milk stage. For forage sorghums, dry matter increased from the late-milk to the late dough stage, and in some studies dry matter increased from the late-dough to the hard-grain stage, but in others decreased. For both grain and forage sorghum, whole-plant dry matter fraction increased with maturity. The fraction of moisture in the crop can affect transport costs and storage choices and losses.

There are a number of different strategies that can be followed when planting sorghum. These are, however, limited and influenced by site conditions (e.g. available moisture, length of growing season), requirements of the preceding and succeeding crop, and objective(s) in growing sorghum [whether solely for grain, solely for biomass (and sugar), or for both grain and biomass (and sugar)]. 
Table 2. Forage sorghum, sorghum x sudangrass, and sudangrass characteristics based on Virginia, USA conditions (Teutsch, 2006)

\begin{tabular}{|c|c|c|c|}
\hline & Forage sorghum & $\begin{array}{l}\text { Sorghum } \mathbf{x} \\
\text { sudangrass }\end{array}$ & Sudangrass \\
\hline Soil drainage & \multicolumn{3}{|c|}{ Well drained to somewhat poorly drained } \\
\hline Seeds per kg & 29,000 to 44,000 & 44,000 & 121,000 \\
\hline Seeding date & $\begin{array}{l}1-2 \text { weeks after corn, soil } \\
\text { temperature at least } 16^{\circ} \mathrm{C}\end{array}$ & \multicolumn{2}{|c|}{$\begin{array}{l}2 \text { weeks after corn, soil temperature at least } \\
18^{\circ} \mathrm{C}\end{array}$} \\
\hline Seeding depth $(\mathrm{cm})^{\mathrm{a}}$ & $2.5-3.8$ & \multicolumn{2}{|c|}{$1.3-2.5$} \\
\hline Seeding rate $\left(\mathrm{kg} \mathrm{ha}^{-1}\right)$ & $\begin{array}{c}6-11 \text { for wide rows } \\
17-22 \text { broadcast }\end{array}$ & $\begin{array}{c}22-34 \text { drilled } \\
34-45 \text { broadcast }\end{array}$ & $\begin{array}{c}17-22 \text { drilled } \\
28-39 \text { broadcast } \\
\end{array}$ \\
\hline Soil pH & $\begin{array}{l}\text { Will grow at 5.5, optimum } \\
6.0-6.5\end{array}$ & \multicolumn{2}{|c|}{ Optimum $6.0-6.5$} \\
\hline $\begin{array}{l}\text { Forage yield as silage (wet } \\
\mathrm{Mg} \mathrm{ha}^{-1} \text { ) }\end{array}$ & $34-67^{\mathrm{b}}$ & \multicolumn{2}{|c|}{$27-34$ at $35 \%$ dry matter } \\
\hline
\end{tabular}

${ }^{\mathrm{a}}$ For Virginia with its heavier soils

${ }^{\mathrm{b}}$ No dry matter percent given

Photoperiod sensitive sorghums begin reproductive growth (i.e. flowering) when day length reaches a certain threshold (ranges from 11.5 to 13.5 hours). This threshold depends on the particular genotype. If biomass is the desired product, sorghums with a photoperiod shorter than day length at the end of the growing season (first frost in temperate climates) allows the crop to occupy the maximum amount of the growing season and maximize biomass production. In areas with longer growing seasons, it may be possible to grow a ratoon crop of sorghum (i.e. sorghum is harvested and then a second crop grows back from the roots). If a ratoon crop is desired, then a longer photoperiod would be selected. Photoperiod sensitive sorghums generally do not set seed under Midwestern, USA conditions. Sorghums should be selected for an appropriate photoperiod for the region where they are grown and the goal for which they are grown (biomass versus biomass plus grain). There are also photoperiod insensitive sorghums. Photoperiod insensitive sorghum will begin reproductive growth after a certain length of time, regardless of day length. Grain sorghum has been bred so they are photoperiod insensitive and will mature in a set number of days.

\section{SORGHUM BIOMASS YIELD EXPERIMENTS}

Purdue University (United States) carried out a biomass research project in Indiana, a part of which dealt with sorghum (Cherney et al., 1990; Johnson et al, 1991). Small plot studies were used in which plot size was designed to eliminate edge effects (yields are higher on the edge of a field exposed to additional sunlight and less competition. Yields were based on total above ground biomass. Note that yields from small plot research studies are generally higher than those obtained from actual operational scale farms. Fertilization for other than nitrogen was based on soil tests. They found the following results:

- When planting at two different densities (43,000 and 260,000 seeds ha ${ }^{-1}$ ), there was no yield advantage to the higher density. [The authors do not indicate specifically whether this applied to both forage and sweet sorghum, but it presumably does.] There was less lodging at the lower density, but not for all varieties (Table 3).

- Two cuttings reduced lodging, but at too great a reduction in yield (Table 4).

- Lodging resistance is critical for top yields.

- There was evidence from Caravetta et al. (1990) that increasing within row spacing may reduce lodging. In addition to breeding for lodging resistance there may also be agronomic 
management practices that may reduce lodging.

- Taller plants did not necessarily produce higher yields (Table 3).

- Sorghum double cropped with winter rye for four consecutive years had declining yields over time (Table 5).

- Sweet sorghum and sorghum x sudangrass interseeded into perennial grasses was not viable, yielding only $0.03-3.31$ dry $\mathrm{Mg}_{\mathrm{ha}}{ }^{-1}$.

Table 3. Sorghum yields and lodging in Indiana, USA in 1990 (Johnson et al, 1991)

\begin{tabular}{|c|c|c|c|c|c|}
\hline \multirow{4}{*}{ Genotype } & \multirow{2}{*}{\multicolumn{2}{|c|}{ Yield $^{\mathrm{a}}$}} & \multirow{3}{*}{ Height } & \multirow{2}{*}{\multicolumn{2}{|c|}{$\begin{array}{c}\text { Lodging } \\
\text { Population (plants ha }{ }^{-1} \text { ) }\end{array}$}} \\
\hline & & & & & \\
\hline & Total & Grain & & $4.3 \times 10^{-4}$ & $2.6 \times 10^{-5}$ \\
\hline & \multicolumn{2}{|c|}{ Dry Mg ha ${ }^{-1}$} & $\mathbf{m}$ & \multicolumn{2}{|c|}{$1=$ flat, $5=$ =rect } \\
\hline Pioneer 931 & 24.7 & 2.02 & 4.64 & 4.92 & 4.83 \\
\hline Vartan 3192 & 24.1 & 0.10 & 4.37 & 4.50 & 4.17 \\
\hline NK Sucrosorgo 506 & 22.6 & 1.48 & 4.36 & 5.00 & 4.92 \\
\hline Grassl & 21.7 & 0.28 & 3.69 & 4.22 & 3.08 \\
\hline Vartan 3 & 20.6 & 0.01 & 4.21 & 4.67 & 4.88 \\
\hline Funk’s G 1990 & 19.7 & 0.00 & 3.74 & 5.00 & 4.92 \\
\hline Vartan 2319 & 19.7 & 0.01 & 5.08 & 4.00 & 4.17 \\
\hline Pioneer 811F & 19.2 & 0.00 & 3.38 & 5.00 & 5.00 \\
\hline Golden Harvest H-58 & 18.6 & 3.07 & 3.32 & 3.83 & 3.67 \\
\hline Meridian 81E & 18.3 & 1.11 & 3.68 & 4.22 & 3.67 \\
\hline Asgrow Titan R & 17.8 & 5.30 & 2.78 & 3.00 & 2.00 \\
\hline Taylor-Evans Milkmaker & 17.7 & 4.14 & 3.04 & 2.08 & 1.67 \\
\hline DekalbFS25E & 17.5 & 4.09 & 3.00 & 4.33 & 2.42 \\
\hline Casterline Silo Plus & 17.0 & 4.29 & 2.91 & 2.00 & 1.50 \\
\hline Taylor-Evans Silomaker & 17.0 & 5.49 & 2.58 & 3.58 & 1.00 \\
\hline Garrison Seed Sile-All & 16.5 & 4.78 & 2.96 & 2.08 & 1.50 \\
\hline $\mathrm{NC}^{+} 965$ & 16.5 & 2.68 & 3.29 & 3.58 & 3.17 \\
\hline PAG FS466 & 16.4 & 3.96 & 2.47 & 4.08 & 2.92 \\
\hline Tall corn hybrid (Dekalb 711) & 23.1 & 10.66 & & & \\
\hline
\end{tabular}

${ }^{a}$ Crops were harvested on 3 and 12 October (at the end of the growing season) from 2 sites

${ }^{\mathrm{b}}$ Corn hybrid for comparison

Table 4. Sorghum yields in Indiana, USA in 1989 (Cherney et al, 1990)

\begin{tabular}{|l|c|c|}
\hline & One harvest & Two harvests (total) \\
\hline & \multicolumn{2}{|c|}{ dry Mg ha $^{-\mathbf{1}}$} \\
\hline Dekalb-Pfizer FS25E & 25.6 & 17.4 \\
\hline M-81E sweet sorghum & 27.5 & 15.6 \\
\hline Vartan 2319 & 21.4 & 12.8 \\
\hline PAG FS-466 & 23.1 & 16.2 \\
\hline Funk's G 1990 & 31.4 & 15.2 \\
\hline Pioneer 931 & 30.5 & 19.0 \\
\hline NK Sucrosorgo 506 & 33.0 & 18.0 \\
\hline
\end{tabular}

Timing of planting can greatly influence yield. In 1988, a severe drought year, sorghum planted in early May, when there was still adequate soil moisture yielded up to 33 dry $\mathrm{Mg} \mathrm{ha}^{-1}$, while sweet sorghum and sorghum x sudangrass planted in late May averaged only 8.6 dry $\mathrm{Mg} / \mathrm{ha}$. Corn planted at 
the same time as the sorghum in early May yielded only 4 - 5 dry $\mathrm{Mg} \mathrm{ha}^{-1}$. The combined yield of sweet sorghum double cropped with rye was up to 31 dry $\mathrm{Mg} \mathrm{ha}^{-1}$.

Table 5. Sorghum double cropped with winter rye for four years in Indiana, USA had declining yield over time (Cherney et al, 1990)

\begin{tabular}{|c|c|c|}
\hline Year & Sorghum x sudangrass & Sweet sorghum \\
\hline & \multicolumn{2}{|c|}{ Dry Mg ha $^{\mathbf{1}}$} \\
\hline 1985 & 16.4 & 22.2 \\
\hline 1986 & 12.6 & 19.1 \\
\hline 1987 & 10.6 & 15.8 \\
\hline $1988^{\mathrm{a}}$ & 8.3 & 8.9 \\
\hline
\end{tabular}

${ }^{a}$ Average over 4 nitrogen treatments $\left(0,50,100,150 \mathrm{~kg} \mathrm{~N} \mathrm{ha}^{-1}\right), 4$ replicates, 4 sites, 2 tillage treatments

b1988 was an extreme drought year

Monk et al (1984) report on sorghum improvement for energy. They found a significant correlation between height and biomass production, but note that lodging can be as serious issue with tall sorghums, especially those with significant grain production.

The Regional Feedstock Partnership Program sponsored by the U.S. Department of Energy is conducting field trials of a number of biomass crops, including sorghum (Owens, 2009). In 2008, sorghum was planted on 0.05 to 0.10 ha plots at 7 sites in Texas (2 sites), Iowa, Kansas, Kentucky, Mississippi, and North Carolina. Two photoperiod-sensitive energy sorghum hybrids (from Ceres and Edenspace), two photoperiod-sensitive forage sorghum hybrids, a sweet sorghum, and a grain sorghum (as a check) variety were planted and harvested in 2008. The Iowa site was not harvested in 2008. A single, end of season harvest was made. Nitrogen was applied as recommended for forage sorghum and no irrigation was applied. Grain sorghum, forage sorghum, and energy sorghum yielded 9, 27, and 27-34 dry $\mathrm{Mg} \mathrm{ha}^{-1}\left(4,12\right.$, and 12-15 dry tons acre $\left.^{-1}\right)$. [Experimental hybrids resulted in about a 20\% yield gain over nonhybrids, a 4.5 to 6.7 to dry $\mathrm{Mg} \mathrm{ha}^{-1}$ (2-3 dry tons acre ${ }^{-1}$ yield) increase]. In 2009, the grain sorghum was not planted and in addition to the two forage, two energy sorghum hybrids, and the sweet sorghum variety; a sweet sorghum hybrid was to be planted.

Oklahoma State University is looking into developing sweet sorghum as a crop for Oklahoma (Anon, 2008). At various locations the university is evaluating: yield of 4 varieties, staggered planting dates to develop a larger harvest window, nitrogen response, and effect of irrigation versus no irrigation.

\section{SORGHUM HYBRIDS}

One strategy for increasing sorghum yield is through the use of hybrids. As noted above, Owens (2009) reported 20\% higher yield from experimental sorghum hybrids in 2008. Reddy et al (2006) report that sorghum grain yields in India and China increased by $50 \%$ and $47 \%$, respectively, from 1960 to 1996. This corresponds to the period of adaption of hybrids in these countries, although other factors such as increased fertilization and better weed control may also have contributed to increased yields. According to Reddy et al (2008) hybrids are early maturing and need less water than varieties (i.e. sorghums that are not hybrids).

As of October 2009, commercial seeds for energy sorghum in the United States were available from Ceres (2009) (in cooperation with Texas A\&M AgriLife Research) (referred to by Ceres as "highbiomass sorghum") and Edenspace. Ceres has two sorghum and two sorghum x sudangrass cultivars available. All four are photoperiod-sensitive, non-heading hybrids. The two sorghums are for single cuts, while the two sorghum $\mathrm{x}$ sudangrasses are suitable for multiple cuts in a growing season. 
Edenspace refers to their hybrid seed product for cellulosic biofuels production as Energy Sorghum $\mathrm{tm}_{\mathrm{tm}}$ with Linebacker $_{\text {tm }}$ being the first available (National Sorghum Producers, 2008). It is a nontransgenic, photoperiod-sensitive forage sorghum.

\section{WATER USE}

In an FAO document (from the mid 1990s) on sorghum in China, sorghum water requirements are stated as 350 to $700 \mathrm{~mm}$, depending on the length of the growing cycle (short-growth variety 90 days to long-growth variety 130 days). For optimum yields on good soil, short-growth, average-growth, and long-growth varieties requires 500 to 600 (20 to 24), 650 to 800 (26 to 31), and 950 to 1100 (37 to 43) $\mathrm{mm}$ (inches) of well distributed rainfall, respectively (Natural Resources Institute, no date).

Water use efficiency (WUE) is a measure of yield per unit of water consumed. Water use and WUE vary by site conditions. In western Kansas, grain sorghum requires 46 to $56 \mathrm{~cm}$ (18 to 22 inches), while in the eastern (more humid) part of the state 25 to $50 \mathrm{~mm}$ (1 to 2 inches) less is required (KSUAES\&CES, 1998). One must be careful when utilizing the concept of WUE. A description of the complexities of utilizing WUE can be found in Jørgensen and Schelde (2001). One can find statements such as sorghum requires $1 / 3$ less water than corn or sorghum requires only half the water of corn. The FAO document on China states that for sorghum, maize, and wheat the transpiration ratio is 141,170 , and $241 \mathrm{~kg} \mathrm{~kg}^{-1}$ plant material, respectively (Natural Resources Institute, no date). [Note: it is not stated in this reference whether plant material is total above ground biomass or just the grain fraction.] For grain sorghum grown in the North Plains of Texas over the 6-year period of 1998 to 2003, water consumption was 1060 and $842 \mathrm{~kg}$ water kg-1 grain for dryland and irrigated production, respectively (New, 2004). [The original units in New (2004) are 213 and $269 \mathrm{lb}_{\text {grain }} \mathrm{acre}^{-1} \mathrm{in}^{-1}$ water for dryland and irrigated production, respectively.]

Conventional wisdom suggests that: under the driest conditions millet is preferred to (produces more than) sorghum and maize (corn), under semi-arid conditions sorghum is preferred to millet or sorghum, and with ample moisture corn performs best. Singh and Singh (1995) tested this belief for sorghum, maize, and millet in an experiment during the hot dry season (April-June) in North India in 1979 and 1980 at four irrigation levels that are described as: unstressed $\left(\mathrm{S}_{0}\right)$, mildly stressed $\left(\mathrm{S}_{1}\right)$, moderately stressed $\left(\mathrm{S}_{2}\right)$, and severely stressed $\left(\mathrm{S}_{3}\right)$. Results for dry matter production and WUE (based on total above ground biomass) are shown in Table 6. They found that maize and sorghum performed best at unstressed conditions. Just because a crop has a higher WUE does not mean it has a higher biomass yield. Different crops draw different amounts of water from different parts of the soil profile. Sorghum draws water from more of the soil profile than corn. In Table 6 below, at irrigation level $S_{1}$, maize has a higher WUE than sorghum, but it does not have a higher yield (they are equal).

Table 6. Biomass production, evapotranspiration, and water use efficiency for corn, sorghum, and millet in Northern India in 1979 and 1980 (Singh and Singh, 1995)

\begin{tabular}{|l|c|c|c|c|c|c|c|c|c|}
\hline $\begin{array}{c}\text { Irrigation } \\
\text { level }\end{array}$ & \multicolumn{3}{|c|}{ Biomass (dry Mg ha ${ }^{-\mathbf{1}}$ ) } & \multicolumn{3}{c|}{ Evapotranspiration (mm) } & \multicolumn{2}{c|}{$\begin{array}{c}\text { Water use efficiency (dry } \\
\text { kg ha }^{-1} \mathbf{~ m m}^{-1} \text { ) }\end{array}$} \\
\cline { 2 - 11 } & Maize & Sorghum & Millet & Maize & Sorghum & Millet & Maize & Sorghum & Millet \\
\hline $\mathrm{S}_{1}$ & 9.0 & 9.0 & 8.3 & 567 & 582 & 568 & 15.9 & 15.4 & 14.6 \\
\hline $\mathrm{S}_{2}$ & 5.2 & 7.1 & 5.9 & 403 & 432 & 429 & 12.8 & 16.4 & 13.8 \\
\hline $\mathrm{S}_{3}$ & 4.7 & 6.1 & 5.4 & 342 & 329 & 331 & 13.7 & 18.5 & 16.3 \\
\hline $\mathrm{S}_{4}$ & 3.0 & 4.1 & 4.0 & 276 & 288 & 224 & 11.0 & 14.4 & 17.9 \\
\hline
\end{tabular}

Farré and Faci (2004) compared water use for sorghum and maize in Zaragoza, Spain, reporting total above ground biomass and grain yields, harvest index (grain fraction of total above ground biomass), 
and irrigation WUE for grain. Plant densities were 52,000 and 217,000 ha ${ }^{-1}$ for maize and sorghum, respectively. Reference evapotranspiration was $695 \mathrm{~mm}$ from sowing to maturity. Irrigation water was applied such that for 6 treatments water applied decreased from T-1 to T-6, with T-1 receiving the full amount of water required. Consistent with Singh and Singh (1995), they found sorghum extracted more water from the deeper soil layers and maize from the upper soil layers. Yields, harvest index, and irrigation WUE for the six water treatments are in Table 7.

Table 7. Yields, harvest index, and irrigation water use efficiency (WUE) for maize and sorghum at Zaragoza, Spain in 1995 (Farré and Faci, 2004)

\begin{tabular}{|l|c|c|c|c|c|c|c|c|}
\hline Treatment & \multicolumn{2}{|c|}{ Biomass (dry Mg ha $\left.{ }^{-1}\right)$} & \multicolumn{2}{c|}{ Grain $\left(\right.$ dry Mg ha $\left.^{-1}\right)$} & \multicolumn{2}{c|}{ Harvest index } & \multicolumn{2}{c|}{$\begin{array}{c}\text { Irigation WUE (g } \\
\left.\text { grain } \mathrm{m}^{-2} \mathrm{~mm}^{-1}\right)\end{array}$} \\
\hline & Maize & Sorghum & Maize & Sorghum & Maize & Sorghum & Maize & Sorghum \\
\hline T-1 & 21.4 & 18.4 & 10.8 & 8.54 & 0.51 & 0.49 & 1.95 & 1.65 \\
\hline T-2 & 17.4 & 16.4 & 8.79 & 7.42 & 0.50 & 0.47 & 1.85 & 1.70 \\
\hline T-3 & 11.0 & 13.0 & 4.80 & 6.30 & 0.43 & 0.46 & 1.25 & 1.75 \\
\hline T-4 & 7.00 & 10.7 & 1.95 & 4.88 & 0.28 & 0.46 & 0.75 & 2.05 \\
\hline T-5 & 4.85 & 7.28 & 0.558 & 2.65 & 0.12 & 0.37 & 0.30 & 1.50 \\
\hline T-6 & 3.57 & 5.22 & 0.095 & 0.643 & 0.03 & 0.13 & 0.10 & 0.65 \\
\hline
\end{tabular}

McCorkle et al (2007) report that in the Panhandle region of Texas, where the availability of irrigation water is becoming a bigger issue, in field trials over the period 2001 to 2003, comparing sorghum silage to maize silage, yields ranged from 43.0 to $60.3 \mathrm{Mg} \mathrm{ha}^{-1}$ (19.2 to 26.9 tons acre ${ }^{-1}$ ) for sorghum silage and 53.3 to $57.1 \mathrm{Mg} \mathrm{ha}^{-1}$ (23.8 to 25.5 tons acre ${ }^{-1}$ ) for maize, but to grow sorghum silage required 40 to 53 percent less water than maize silage.

One practice in semi-arid areas (e.g. western Great Plains and High Plains in the United States) is to fallow (a year in which no crop is planted), such as in wheat-fallow or sorghum-fallow (one crop in 2 years), or wheat-sorghum-fallow (2 crops in 3 years) rotations. The fallow year allows moisture to accumulated in the soil and be available for a crop the next year. Although the fallow year allows yields in succeeding years to be greater, over the rotation cycle total yield may not increase by using a fallow year in the rotation (Table 8, e.g. compare over 2 years continuous sorghum $4.37 \mathrm{Mg} \mathrm{ha}^{-1}$ versus sorghum-fallow $4.21 \mathrm{Mg} \mathrm{ha}^{-1}$, or over 6 years where continuous sorghum gives a greater yield than any of the rotations utilizing fallow).

Table 8. Dryland sorghum and winter wheat yields (Mg ha-1) in continuous and fallow rotations 19731987 at Tribune, Kansas, USA (Norwood et al 1990)

\begin{tabular}{|l|c|c|c|c|c|c|c|}
\hline Rotation & $\begin{array}{c}\text { Continuous } \\
\text { wheat }\end{array}$ & \multicolumn{2}{|c|}{ Wheat-sorghum-fallow } & \multicolumn{2}{c|}{ Wheat-fallow } & $\begin{array}{c}\text { Continuous } \\
\text { sorghum }\end{array}$ & $\begin{array}{c}\text { Sorghum- } \\
\text { fallow }\end{array}$ \\
\hline Tillage & Conventional $^{1}$ & Conventional $^{1}$ & Reduced & Conventional $^{1}$ & Reduced & Conventional $^{1}$ & Conventional $^{1}$ \\
\hline Wheat & $1.14^{\mathrm{c}}$ & $2.28^{\mathrm{b}}$ & $2.66^{\mathrm{a}}$ & $2.38^{\mathrm{ab}}$ & $2.68^{\mathrm{a}}$ & & \\
\hline Sorghum & & $2.40^{\mathrm{c}}$ & $3.29^{\mathrm{b}}$ & & & $2.18^{\mathrm{c}}$ & $4.21^{\mathrm{a}}$ \\
\hline $\begin{array}{l}2 \text { year } \\
\text { yield }\end{array}$ & 2.27 & & & 2.38 & 2.68 & 4.37 & 4.21 \\
\hline $\begin{array}{l}\text { 3 year } \\
\text { yield }\end{array}$ & 3.41 & 4.69 & 5.96 & & & 6.55 & \\
\hline $\begin{array}{l}\text { 6 year } \\
\text { yield }\end{array}$ & 6.82 & 9.38 & 11.92 & 7.14 & 8.03 & 13.10 & 12.63 \\
\hline
\end{tabular}

${ }^{1}$ stubble mulch (leaving residue on the surface while farming) was the conventional tillage practice used

Water is a limiting factor of production in many areas. One wants to match an appropriate crop and genotype or hybrid with available soil moisture. There is no advantage to planting a high yielding crop 
if the water is not available to support the high biomass yield. According to Koch (no date), sorghum can produce a ton of forage with 6 to $8 \mathrm{~cm}$ (2.5 to 3 inches) of [total] water. Sorghums are known for their ability to extract soil moisture.

\section{HARVEST AND STORAGE SYSTEMS}

Grain sorghum is harvested in a similar fashion as are other small grains, such as wheat. In modern agriculture, grain sorghums have been bred for uniform height so they may be efficiently harvested with a combine. The logistics of grain sorghum (harvest, transport, storage) are well developed and similar to maize grain. Sorghum grain is usually dried to a moisture content of $10 \%$ to $12 \%$ and has a bulk density of 520 to $720 \mathrm{~kg} \mathrm{~m}^{-3}$ (32 to $45 \mathrm{lb} \mathrm{ft}^{-3}$ ) which allows for storage and efficient transport (Natural Resources Institute, No date).

Tall sorghums (forage, sweet, energy) are harvested with a forage or sugar cane harvester (see Figure 2). High tonnages require large self-propelled harvesters, which have high capital costs. However, field and road conditions may not permit, either physically or economically, use of large-scale harvest equipment and it may make sense to us a tractor-pulled forage harvester (Pari et al, 2008). Pari et al (2008) report on European efforts to develop a sweet sorghum harvester appropriately scaled to European conditions.

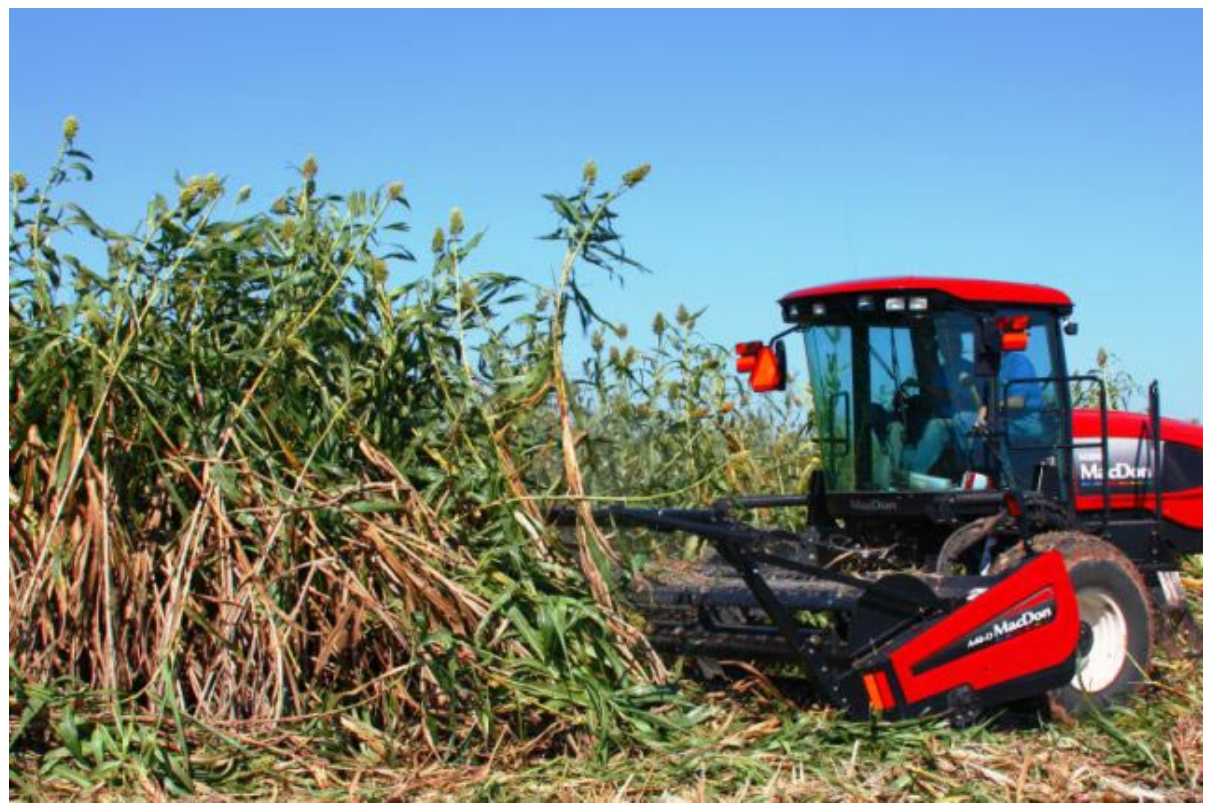

Figure 2. Energy sorghum harvested as a cellulosic bioenergy feedstock with a forage harvester (photo courtesy of Dave Jordan, MacDon Industries, LLC).

For cost-effective harvesting, it is advantageous to have an extended harvest season or, in the case of an area also growing sugar cane, to have the sorghum harvest season offset from the sugar cane harvest season and be able to utilize sugar cane harvesters that would otherwise be idle. Sweet sorghum is similar to sugar cane in that the juice (sugar) in the stalk needs to be processed fairly rapidly; otherwise sugars in the stalk are lost. Reddy et al (2008) show data on how the amount of sugar decreases over the course of four days (Table 9). Given that the sugar in sweet sorghum, like in sugar cane, needs to be processed rapidly, technologies need to be developed to stabilize the juice and maintain the sugar for later processing so that the processing season for the sugar could be extended. At Oklahoma State University, USA, Anon (2008) refers to a process that includes a newly designed field harvester that 
can press and collect juice from sweet sorghum in a single pass and utilization of large bladders for on farm fermentation. Grassi (no date) refers to a "first commercial innovative mechanical drying and compaction technology" for stabilization of "humid" lignocellulosic residues that can produce pellets (with neither predrying nor a binder) at a processing cost of about $35 \mathrm{Mg}^{-1}$ and a bulk density of about $600 \mathrm{~kg} \mathrm{~m}^{-3}$. The moisture content of the pellets is not given. [The Grassi reference is from 2005 or later as it references prices from November 2005 in its third slide.]

Table 9. How sweet sorghum sugar content is affected by delay in crushing (Reddy et al, 2008)

\begin{tabular}{|c|c|c|c|c|}
\hline $\begin{array}{l}\text { Crushing (days } \\
\text { after harvest) }\end{array}$ & $\begin{array}{l}\text { Juice extraction (L } \\
\left.\quad \times 10^{3} \mathrm{ha}^{-1}\right)\end{array}$ & Brix reading & $\begin{array}{l}\text { Sugar yield } \\
\left(\mathrm{Mg} \mathrm{ha}^{-1}\right)\end{array}$ & $\begin{array}{l}\text { Sugar reduction } \\
\text { from harvest day } \\
(\%)\end{array}$ \\
\hline 0 & 42.4 & 18.5 & 2.62 & - \\
\hline 1 & 40.6 & 19.2 & 2.47 & 5.7 \\
\hline 2 & 35.0 & 20.9 & 2.18 & 16.8 \\
\hline 3 & 37.6 & 21.4 & 2.20 & 16.0 \\
\hline
\end{tabular}

An additional question with sweet sorghum (and other high tonnage sorghums) is whether the whole plant should be processed or whether the leaves should be discarded. For sweet sorghum, should only the stalk be processed and both the grain and leaves be discarded? For sweet sorghum with little grain, this is not an issue, but if sweet sorghum is developed for both its sugar and grain, appropriate harvesting technology must be developed to harvest both the stalk and grain.

Moisture content presents a challenge for utilizing non-grain sorghum. Generally, sorghums grown for biomass will be high in moisture content at harvest (60\% to $70 \%$ on a wet basis), although when grown for biomass, as opposed to for animal feed, it may be possible to field dry to a lower moisture content. High moisture content may limit the amount of dry matter that can be carried in a truck load. For example, in the United States the typical maximum load that can be carried by a truck is about $22.7 \mathrm{Mg}(50,000 \mathrm{lb})$ and the largest volume a trailer can have is about $140 \mathrm{~m}^{3}\left(5,000 \mathrm{ft}^{3}\right)$. At $60 \%$ moisture content, the maximum dry matter content of the load is 9.1 dry $\mathrm{Mg}(20,000 \mathrm{dry} \mathrm{lb})$. In this largest sized trailer, this load is achieved with a density of 64 dry $\mathrm{kg} \mathrm{m}^{-3}\left(4.0 \mathrm{dry} \mathrm{lb} \mathrm{ft}^{-3}\right)$. Chopped sorghum has a density of between about 70 and 120 dry kg m$~^{-3}$ (4.4 and $7.5 \mathrm{dry} \mathrm{lb} \mathrm{ft}^{-3}$ ), which is much lower than grain sorghum. At this high moisture content the load is limited by the weight, and the volume would not be fully utilized. If the sorghum could be reduced to a moisture content of $40 \%$, then the load could be 13.6 dry $\mathrm{Mg}$ (30,000 dry lb) and the maximum weight allowable would be achieved by a density of 96 dry $\mathrm{kg} \mathrm{m}^{-3}\left(6.0 \mathrm{dry} \mathrm{lb} \mathrm{ft}^{-3}\right)$. Transport options are limited by moisture. It may also be that road characteristics limit the size of trailer, and a higher bulk density may be desirable, if highway conditions support the higher load weight.

Texas A\&M is working to design a collection system similar to a cotton module for packaging sorghum for transport and storage. [A cotton module is built in a module builder (about 9 meters long, 4 meters high, and 3 meters wide) by dumping a number of loads of harvested cotton into the module builder and compressing each load (as a garbage truck does with garbage) until the module is built and discharged. It is shaped similar to a giant bread loaf and weights about $10 \mathrm{Mg}$ (Cotton.org, 2010 Wikipedia, 2010).] This most likely will require modification of the cotton module technology. After harvest the sorghum is transferred to the module builder using a silage wagon. The biomass is then compressed into a module and surrounded with a protective cover. The high moisture content of sorghum is a challenge in compressing the material into a module (Fannin, 2009). High moisture contents may necessitate the use of ensiling for storing sorghum, or a cost effective means of reducing sorghum moisture content below $20 \%$ so that a dry storage method such as baling could be used. 
Another option is some type of distributed intermediate processing. For example, a pyrolysis unit could be used to process the sorghum into a liquid that would be far denser than the sorghum biomass itself. The liquid can be stored and more economically transported. In the case of pyrolysis the optimal feedstock moisture content is around $10 \%$. Pelletization and cubing are other options, but again optimal moisture content is around $10 \%$.

Storage is an issue with biomass crops and sorghum is no exception. The seasonality of production and the desire to operate a conversion facility year round may necessitate storage of biomass. One means of minimizing storage is to pursue strategies for expanding the sorghum harvest season (e.g. planting varieties with differing maturities or utilizing multiple cuttings on some sorghum fields). Another is to utilize multiple feedstocks with differing harvest seasons along with sorghum (e.g. winter rye or trees).

\section{SORGHUM AND SUGAR CANE}

While sweet sorghum can give sugar yields comparable to sugar cane, it is not used for refined sugar production because its high sugar content interferes with sucrose crystallization and hastens the inversion of sucrose to glucose and fructose (Tew et al, 2008).

One proposed use of sweet sorghum is to plant it at times when sugar cane lands are fallow. Sugar cane is a hybrid with multiple parents. Sugar cane is vegetatively propagated because the seed produced does not breed true (i.e., it could express any of the parents and would not produce a uniform field or product). Under normal Florida conditions, for example, the seed produced will not germinate. Sugar cane, though a perennial, needs to be replanted about every two to five years in the United States. [In other parts of the world, replanting may occur less frequently, every 7+ years.] In the continental United States, sugar cane fields are replanted in Louisiana from August through October, usually in September (Tew et al, 2008) and in Florida from late August through January (Baucum et al, 2006). Part of existing sugar cane production fields are used to take vegetative material and replant fields. The later one waits to replant the sugar cane field, the less area one has to sacrifice to seed cane, as the per unit area production of sugar cane increases from August through September. However, research in Louisiana has found that planting in August leads to higher subsequent sugar yields in three out of five hybrids that occupy $99 \%$ of sugar cane acreage in Louisiana (Viator et al, 2005). In the continental US, sugar cane is harvested for sugar in November through March. If sugar cane fields that need to be replanted are replanted by January, then there is no fallow period. However, if a sugar cane field is not replanted by January, then one has to wait until the subsequent August-January period to replant and those fields will be fallow from after harvest until replanting (i.e. during a summer growing season). Sweet sorghum could be planted instead of fallowing the land (Baucum et al, 2006). Another possible crop to grow in this potentially fallow period is soybeans.

For sorghum to be grown during fallow on sugar cane lands, it would need to be harvested not later than mid-August, to allow optimum replanting of sugar cane. In an experiment near Schriever, LA, USA in 2003 and 2004, Tew et al (2008) evaluated how sorghum yield (five sweet sorghum varieties and two sorghum $\mathrm{x}$ sudangrass varieties) and total ethanol produced are affected by harvest date (Table 9). (Only the highest yielding varieties are reported in Table 10.) Planting occurred on 29 April 2003 and 6 May 2004. Stalks were stripped of leaves and seed heads to simulate what would likely occur if the sorghum were harvested with a sugar cane harvester. A mid-April planting and mid-August harvest would allow approximately a 120 day growing season. Note that in 2003 and 2004, 26 August and 2 September were 119 days after planting, respectively. In 200416 August was 101 days after planting. A mid-April planting might result in a lower yield than indicated in Table 10 (at equal days 
after planting) because of less growing degree days.

According to information presented by Reddy et al (2008), sweet sorghum needs less water than sugar cane. A sweet sorghum crop growing in India needed $4,000 \mathrm{~m}^{3}$ for a 4-month period versus $36,000 \mathrm{~m}^{3}$ of water for a sugar cane crop growing over 12 months. It is possible under Indian conditions to grow two sweet sorghum crops while a single sugar cane crop is growing. The two sweet sorghum crops would require $8,000 \mathrm{~m}^{3}$ of water. They report that the sugar in the stalk of two sweet sorghum crops and one sugar cane crop would produce 2800 and $5600 \mathrm{l} \mathrm{ha}^{-1}$, respectively. In addition the sweet sorghum can produce 2.0 to $2.5 \mathrm{Mg} \mathrm{ha}^{-1}$ grain. [The original source for the sweet sorghum water use is Soltani and Almodares (1994).]

Table 10. How harvest timing (days after planting) affect sorghum yield and total ethanol from sorghum in Louisiana (Tew et al, 2008)

\begin{tabular}{|c|c|c|c|c|c|c|c|c|c|}
\hline \multirow{2}{*}{$\begin{array}{l}\text { Days } \\
\text { after } \\
\text { planting }\end{array}$} & $\begin{array}{l}\text { MMR } \\
33 / 47^{\mathrm{a}} \\
\end{array}$ & Theis $^{\mathrm{b}}$ & M81-E & $\begin{array}{l}\text { MMR } \\
33 / 47 \\
\end{array}$ & Theis & M81-E & $\begin{array}{l}\text { MMR } \\
33 / 47 \\
\end{array}$ & Theis & M81-E \\
\hline & \multicolumn{3}{|c|}{ Hexose sugars $\left(\mathrm{Mg} \mathrm{ha}^{-1}\right)$} & \multicolumn{3}{|c|}{ Fiber $\left(\mathrm{Mg} \mathrm{ha}^{-1}\right)$} & \multicolumn{3}{|c|}{ Ethanol $^{\mathrm{c}}\left(\mathrm{L} \mathrm{ha}^{-1}\right)$} \\
\hline 85 & 3.2 & 5.0 & 4.7 & 10.0 & 14.2 & 11.0 & 5,670 & 8,300 & 6,930 \\
\hline 101 & 5.0 & 8.1 & 6.6 & 14.2 & 14.2 & 12.8 & 8,330 & 10,220 & 8,800 \\
\hline 119 & 6.4 & 9.8 & 8.0 & 20.2 & 15.3 & 13.4 & 11,450 & 11,620 & 9,860 \\
\hline 138 & 8.3 & 10.1 & 9.5 & 23.4 & 16.6 & 15.5 & 13,840 & 12,340 & 11,570 \\
\hline
\end{tabular}

${ }^{\mathrm{a}}$ Sorghum X sudangrass hybrid

${ }^{\mathrm{b}}$ Sweet sorghum

${ }^{\mathrm{c}}$ Estimated theoretical ethanol, based on assuming 1.7 and $2.65 \mathrm{~kg}$ hexose sugar and fiber per L ethanol, respectively

\section{CROP IMPROVEMENT EFFORTS}

Klein et al (2008) identify five distinct phases for grain sorghum improvement efforts in the United States:

1) introduction of a limited number of cultivars (1878-1908),

2) selection of early maturing plants of short stature from heterogeneous populations (19041936),

3) breeding of improved cultivars (short stature, photoperiod insensitive) that are combine harvestable (1930s-1940s),

4) hybrid seed production (1946-present), and

5) conversion of tropical sorghums (tall, photoperiod sensitive) to sorghum usable in temperate climates (short, photoperiod insensitive) and the use of diverse sorghum germplasm for breeding (1963-present)

Starting in 1963, a cooperative effort, now known as the Sorghum Conversion Program, between USDA and Texas A\&M University was begun to convert tropical photoperiod sensitive sorghum into sorghums that would flower and set seed within 50 to 75 days after planting and be ready for harvest within 120 days after planting. These traits would make sorghum a useful crop in the temperate latitudes for grain production. Tropical sorghums are converted by crossing the photoperiod insensitive tropical sorghums with a variety that is insensitive to day length. During the winter, the crossed plants are grown at the Tropical Agricultural Research Station in Mayaguez, Puerto Rico and seed from these are collected and sent to Chillicothe, Texas to be grown during the summer, and display genetic variability for height and maturity. Seeds from short plants with early maturity are sent back to Mayaguez for further crossing. The crossing process continues for 5 to 7 years, until the plants are converted. In addition to height and maturity, breeders incorporate insect and disease resistance, drought tolerance, and improved grain quality (Adams, 1995). According to Klein et al (2008): “The 
conversion program was designed to move recessive dwarfing and photoperiod insensitive genes from a four-dwarf temperate zone variety into the genomes of exotic lines. Through this program over 840 converted and partially converted lines have been developed thereby providing new diverse germplasm that now provides an important source of germplasm used in sorghum improvement programs throughout the world.”

During the 1960s through 1990s, four sweet sorghum varieties were developed by the USDA Sugar Crops Field Station in Meridian, MS; the Mississippi Agricultural and Forestry Experiment Station; and other experiment stations in the southeastern United States (msucare.com, 2009). Four varieties were released (date of release in parentheses): Dale (1970), 115 day maturity; Theis (1974), 130 day maturity; M81-E (1981), 130 day maturity; and Topper 76-6 (1994), 120 day maturity.

The International Crops Research Institute for the Semi-Arid Tropics (ICRISAT) has engaged in research to develop sorghum hybrid parents and from these parents hybrids adapted to Asia, Africa, and the Americas. ICRISAT was established in 1972 in Patancheru, Andhra Pradesh, India with a directive to improve the productivity of sorghum in the semi-arid tropics of Asia, sub-Saharan Africa, and Latin America. Research on hybrid parents began at Patancheru, India in 1978, Sotuba, Mali in 1982, Bulawayo, Zimbabwe in 1985, and Nairobi, Kenya in the early 1990s. Work on hybrid parents done at ICRISAT is documented in Reddy et al (2006). They divide the research into 3 phases, 19781988, 1989-1998, and 1999 onwards. ICRISAT has developed hybrid parents for grain and forage yields. In addition it has worked on resistance to major biotic (e.g. grain mold, shootfly resistance) and abiotic (e.g. moisture) stresses, developed lines with increased high sugar content in the stalks of sweet sorghum, increased forage yield, and developed hybrids adapted to postrainy (or nonrainy) season conditions (for climates such as India). Hybrids are developed on a regional basis.

Research began in 1980 to identify sweet sorghum lines with high sugar content stalks (high Brix values) from the world sorghum germplasm collection at ICRISAT. Two cultivars were selected. In addition, several high Brix sweet sorghum lines from Nigeria, Zimbabwe and from within advanced breeding progeny at ICRISAT were selected. Sweet sorghum research was discontinued at ICRISAT in the late 1990s, but restarted in 2002. By 2005, ICRISAT had released a few varieties (e.g. SSV 84 and SSV 74 and is developing hybrids.

ICRISAT is interested in sorghums that provide both grain and biomass. This is consistent with work in China, where the sweet sorghum hybrid Shennong No. 2 was developed (FAO, 1994).

Reddy et al (2008) presented data for India showing that hybrids of sweet sorghum gave much higher yields of grain and slightly lower sugar yields than [nonhybrid] sweet sorghum varieties tested during both the rainy and nonrainy seasons. Sweet sorghum varieties are more photoperiod sensitive than hybrids studied. Hybrids are earlier maturing and need less water than "pure-line" varieties (Reddy et al, 2005). Reddy et al $(2007,2008)$ also compared two hybrids to a control variety and report days to $50 \%$ flowering was 6 to 9 days less with the hybrids (Table 11). The days to flowering gives an indication of the rate of development of sorghum. They compared hybrids during the rainy and nonrainy season and found that if one wants sugar then one should breed separately for the rainy and post rainy seasons (Table 12). 
Table 11. Hybrids relative to variety in India (Reddy et al; 2007, 2008)

\begin{tabular}{|l|c|c|c|c|c|}
\hline & $\begin{array}{c}\text { Days to 50\% } \\
\text { flowering }\end{array}$ & Brix & $\begin{array}{c}\text { Juice (kl } \\
\left.\text { ha }^{-1}\right)\end{array}$ & $\begin{array}{c}\text { Sugar }(\mathrm{Mg} \\
\left.\text { ha }^{-1}\right)\end{array}$ & $\begin{array}{c}\text { Grain }(\mathrm{Mg} \\
\left.\text { ha }^{-1}\right)\end{array}$ \\
\hline ICSA749 x SSV74 (hybrid) & 85 & 18.0 & 27.2 & 9.15 & 3.28 \\
\hline ICSA511 x SSV74 (hybrid) & 88 & 18.0 & 22.7 & 7.84 & 5.79 \\
\hline SSV84 (variety - control) & 94 & 16.6 & 16.8 & 4.98 & 2.67 \\
\hline
\end{tabular}

${ }^{\mathrm{a}}$ Reddy et al list no units for Brix. Typically Brix is as Degrees Brix $\left({ }^{\circ} \mathrm{Bx}\right)$, a measure of dissolved sugar to water. A $25^{\circ} \mathrm{Bx}$ solution would be $25 \mathrm{~g}$ of sugar and $75 \mathrm{~g}$ of water.

Table 12. How rankings for sugar and grain change between rainy and nonrainy season over 2 years (Reddy et al, 2008)

\begin{tabular}{|c|c|c|c|c|c|c|c|c|c|c|}
\hline & \multicolumn{2}{|c|}{ Brix $(\%)^{\mathrm{a}}$} & \multicolumn{4}{|c|}{ Sugar $\left(\mathrm{Mg} \mathrm{ha}^{-1}\right)$} & \multicolumn{4}{|c|}{ Grain $\left(\mathrm{Mg} \mathrm{ha}^{-1}\right)$} \\
\hline Hybrid & Rainy & Nonrainy & Rainy & Rank & Nonrainy & Rank $^{b}$ & Rainy & Rank & Nonrainy & Rank $^{b}$ \\
\hline $\begin{array}{l}\text { ICSA675 x } \\
\text { SSV74 }\end{array}$ & 16.6 & 10.3 & 6.3 & 1 & 1.1 & 9 & 6.7 & 8 & 7.1 & 8 \\
\hline $\begin{array}{l}\text { ICSA675 x } \\
\text { SPV422 }\end{array}$ & 17.3 & 11.7 & 6.1 & 2 & 0.9 & 14 & 6.6 & 9 & 6.7 & 10 \\
\hline $\begin{array}{l}\text { ICSA324 x } \\
\text { SSV422 }\end{array}$ & 16.5 & 16.1 & 4.8 & 13 & 1.7 & 2 & 4.9 & 17 & 3.9 & 20 \\
\hline $\begin{array}{l}\text { ICSA474 x } \\
\text { E36-1 }\end{array}$ & 13.5 & 14.3 & 4.8 & 14 & 1.7 & 3 & 6.3 & 14 & 6.2 & 15 \\
\hline $\begin{array}{l}\text { NSSH104 } \\
\text { (check) }\end{array}$ & 18.5 & 19.8 & 5.9 & 3 & 1.2 & 8 & 4.2 & 18 & 7.2 & 3 \\
\hline
\end{tabular}

${ }^{\mathrm{a}}$ Reddy et al list the units as \%. Typically Brix is as Degrees Brix $\left({ }^{\circ} \mathrm{Bx}\right)$, a measure of dissolved sugar to water. A $25^{\circ} \mathrm{Bx}$ solution would be $25 \mathrm{~g}$ of sugar and $75 \mathrm{~g}$ of water.

${ }^{\mathrm{b}}$ There were a total of 20 sorghum hybrids grown. Only selected sorghum hybrids are shown

The research in progress at ICRISAT for sweet sorghum identified several promising varieties and several hybrid seed parents and restorers, developed hybrids that are relatively less photoperiod and thermo sensitive and earlier maturing than varieties, and identified several sweet-stalked hybrids that are higher yielding than the best control hybrid (ICRISAT, 2007). Three sweet sorghum varieties had days to 50\% flowering ranging from 69 to 96, while two hybrids had days to 50\%flowering of 65 to 74, depending on the month of planting during November to March. The hybrids (days to $50 \%$ flowering) were much less affected by month of planting and varying day length than the varieties (Reddy et al, 2008).

ICRISAT is cooperating with the Bureau of Agricultural Research (BAR) and the University of Los Baños in the Philippines on production and development of sweet sorghum hybrids (Hernandez, 2009). After the 2008 growing season six hybrids were identified for seed production and characterization.

Texas A\&M University is currently conducting sorghum research on both high biomass and sweet sorghum, and is cooperating with Ceres on research on and commercialization of biomass sorghum. For biomass sorghum, they are developing parental lines with maternal lines that are short to facilitate seed collection and hybrids to produce tall high-biomass plants. These hybrids are photoperiod sensitive do not initiate flowering until day length is less than 12 hours, thereby maximizing the length of growing season and biomass produced. Breeding for a thick stalk helps prevent lodging. In 2007, the forage sorghums used in the breeding program grew to 3.0 to $3.7 \mathrm{~m}$ (10 to 12 feet) tall and yielded

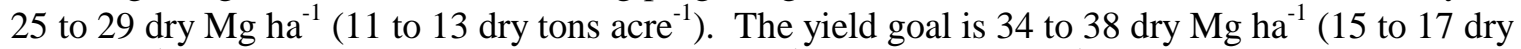
tons acre ${ }^{-1}$ ) in the next few years and 45 dry $\mathrm{Mg} \mathrm{ha}^{-1}\left(20\right.$ dry tons acre ${ }^{-1}$ ) within the next decade, based on conventional breeding. No transgenic breeding is planned because sorghum easily hybridizes with 
johnsongrass [Sorghum halepense (L.) Pers.], an aggressive weedy species. For sweet sorghum, seed is also an issue because the plant puts much of its sugar into the stalk and not seed and the plant is tall, making it mechanically difficult to harvest seed. Texas A\&M is breeding the maternal line short to aid in seed collection. The program seeks to exploit hybrid vigor in sweet sorghum (Schill, 2007).

Qingshan and Dahlberg (2001) describe Chinese efforts in sorghum improvement. Comprehensive and systematic Chinese research on sorghum began in 1951 after the establishment of the People's Republic. From 1956 to 1984 germplasm was collected throughout China, preserving the germplasm resources and laying the foundation for improving sorghum. Most varieties were grain sorghum, but some fodder and sugar varieties were collected. Traits have been identified, including agronomic and nutrition characteristics and screenings for resistance to biotic and abiotic stresses. There is wide variation in days to maturity, from 80 to 190 days. Most local varieties are photoperiod and thermo insensitive. Many accessions are tall, with the tallest being $4.5 \mathrm{~m}$ (15'). Stresses screened for include drought, cold, saline and alkali soils, and various diseases such as head smut, and pests such as the sugar cane aphid and European corn borer. Starting in the late 1950s, improved sorghum varieties began to be released. Chinese sorghum germplasm has been exported to other countries, including the United States, the former USSR, and Australia. Cold tolerance is an important trait available in Chinese germplasm.

As of 2008, there were approximately 168,000 sorghum accessions held at repositories around the world, with the two largest repositories being ICRISAT and USDA. However these collections have not been adequately explored for traits important to the biofuels industry. While the sorghum genome is the second major cereal crop to be sequenced, genetic improvement is difficult without clear targets. At the International Conference on Sorghum for Biofuels in 2008, the feedstock development group stated that for rapid genetic improvements, traits important to the biofuels industry must be defined. They noted that critical traits must take account of cultures and conditions in individual countries and regions. Until other criteria are defined, yield is the most important trait on which to concentrate. Because sorghum is a diploid, compared to other biofuel crops, it is relatively genetically simple and allows for multiple breeding cycles per year (Pederson and Dahlberg, 2008).

There are also sorghums that are lower in lignin content; brown midrib (BMR) mutant lines. The brown midrib trait was identified in sorghum in 1978. The brown midrib trait is available in forage sorghum and sorghum $x$ sudangrass. Standability is an issue with brown midrib sorghum. Forage analysis (e.g. in vitro dry matter digestibility) and animal feeding trials have shown improved digestibility (Burmood, 2003). The lower lignin content may lead to better conversion into ethanol. ICRISAT has been breeding brown midrib sorghums (Reddy et al, no date).

\section{ADAPTATION OF MODERN SORGHUM VARIETIES AND HYBRIDS IN DEVELOPING COUNTRIES}

Tannins can limit the nutritional value of grains, including sorghum. Some tannins form complexes with proteins and proteases in the alimentary tract, reducing protein digestibility. However, the tannins impart bird and insect resistance, and in some cases in traditional foods the phenolics found in red sorghum give desired color and flavor. (Grain sorghum comes in a number of colors, including white, brown, pink, red, and yellow. White sorghum is generally preferred for food products.) (Phenolics are naturally organic compounds and can give foods tastes and smells.) Traditional varieties are generally taller than the dwarf varieties bred for mechanical harvest. However, traditional varieties are open pollinated and farmers can retain seed at harvest for the next planting season. Modern hybrids are generally higher yielding, but only make economic sense when grown with the required inputs of fertilizer, weed control, pest control, and water management. Hybrid seed is more expensive and 
cannot be retained for the next planting season. Varieties with resistance to disease, insects, birds, drought, and acceptable yields of both grain and fodder are preferred by resource-limited farmers (Natural Resources Institute, no date).

\section{HOW TO APPROACH SORGHUM RESEARCH}

Developing sorghum as an energy crop will need to be supported by an integrative research strategy that considers an entire cropping system (where sorghum may be one component) to sustainably and economically produce food, feed, fiber and fuels. Preliminary research questions that need to be explored include:

What sorghum products are desired?

- Both biomass (lignocellulose alone or lignocellulose and sugar) and grain?

- Primarily biomass (and grain produced, if any, is incidental)?

- Sugars (and possibly grain) with the bagasse as a secondary product?

What land will be used?

- Will sorghum replace current food and feed crops, or pasture?

- Will sorghum be integrated in crop rotations (potentially increasing long-term productivity of other crops)?

- Will sorghum be part of an expansion into marginal lands or part of recuperation of abandoned and degraded lands?

In addition to land use and product mix, productivity depends on intensity of production and constraining factors such as water. The feasibility of bioenergy from sorghum will depend on costs of required inputs, efficiency of operations, markets and prices for cropping system outputs and technologies available. For example, with today's conversion technologies, sweet sorghum for conventional ethanol may be the most viable bioenergy option, but in the future, lignocellulosic conversion technology may favor sorghum varieties with higher biomass yields per unit of input than sweet sorghum.

A question to research is whether one is better off utilizing sorghum that is specialized (e.g. energy sorghum for biomass and grain sorghum for grain) or sorghum that is multipurpose (e.g. sweet sorghum that produces both grain and biomass) instead? For example, if grain sorghum is grown on 1 unit of land and energy sorghum on 1 unit of land, will this produce more grain and biomass than a dual purpose sorghum (a sorghum developed for both grain and biomass) grown on 2 units of land? The answer is likely to vary be location.

Another issue to consider is what conversion technologies are available. This will affect the choice of crops grown. For example, sweet sorghum is high in sugar that can be converted into ethanol using currently available technology, whereas conversion of lignocellulose to ethanol is still in the developmental stage. The choice of type of sorghum today would likely be sweet sorghum, but in the future with improvements in lignocellulosic conversion technology it would likely be an energy sorghum that would yield more biomass per unit land area than sweet sorghum. 


\section{WHY SORGHUM AS AN ENERGY CROP AND NEEDED IMPROVEMENTS}

Among potential annual bioenergy crops, sorghum may be advantageous where drought tolerance is important and it can enhance production of other crops (e.g. as seasonal cover crop or in rotations). Sorghum allows farmers flexibility in choice of crop from year to year. It has the potential for high yields (40+ dry $\mathrm{Mg} \mathrm{ha}^{-1} \mathrm{yr}^{-1}$ ). Genetic mapping combined with a relatively fast breeding and field testing cycle facilitate further improvements for bioenergy once desired feedstock characteristics and site requirements are clearly defined. Acknowledging that improvements for bioenergy could potentially diverge from those for feed and food, the following research agenda is proposed:

1) Define traits important for bioenergy and characterize sorghum collections for these traits

2) Develop cost-effective means to stabilize sweet sorghum juice so it does not need immediate processing

3) Increase sugar yields of sweet sorghum for use in the near term as an ethanol feedstock (or to supplement sugar from sugarcane)

4) Increase grain yields for sweet and energy sorghums to explore multi-product potential

5) Develop varieties for high biomass yields (energy sorghum)

6) High and low lignin varieties (high lignin for thermochemical conversion such as gasification or pyrolysis and low lignin for ethanol feedstock)

7) Research cropping systems including

- double cropping where sorghum supplements other grain production to increase overall output while reducing environmental impacts

- cover crop and inter-crop sorghum that helps control weeds and pests for high-value crops (vegetables) while improving soils

While perennial biomass crops may be preferred for environmental benefits (e.g. lower soil erosion, lower fertilizer requirements), annuals such as sorghum provide farmers with more agility to shift crop production in response to market signals. Sorghum's fast breeding cycle, compared to perennials, can help increase bioenergy feedstock production while perennials are being developed. Both perennials and annuals can play important roles in an integrated system designed to minimize input requirements and maximize production of multiple food, feed, fiber and fuel products.

\section{REFERENCES}

Adams, Sean. 1995. Resetting sorghum's internal clock. Agricultural Research, 43(12):18-19. Accessed at: http://www.ars.usda.gov/IS/AR/archive/dec95/sorghum1295.pdf

Alibaba.com. 2008. Tata Chemicals' ethanol plant validates claims on sorghum. Accessed at: http://news.alibaba.com/article/detail/chemicals/100016077-1-tata-chemicals\%2527-ethanol-plantvalidates.html

Anon. 2008. Sweet sorghum: Q \& A with Dr. Dani Bellmer. Sorghum Grower, March 2008, p. 17.

Baucum, L.E., R.W. Rice, and T.J. Schueneman. 2006. An overview of Florida sugarcane. SSAGR-232. Institute of Food and Agricultural Sciences, university of Florida. Accessed at: http://www.floridaplants.com/Reprints/An\%200verview\%20of\%20Florida\%20Sugarcane.htm 
Bennett, A. S., R. P. Anex. 2008. Farm-Gate Production Costs of Sweet Sorghum as a Bioethanol Feedstock. Transactions of the ASABE 51(2): 603-613

Bolsen, Keith K. 2002. Grain and forage sorghum silages: A review of cultivar, maturity, and processing effects. Accessed at:

http://www.ksre.ksu.edu/pr_silage/publications/Sorghum\%20Silage\%20A\%20Review.pdf

Burmood, Tom. 2003. Brown midrib sorghum forage. Accessed at: http://www.uwex.edu/ces/forage/wfc/proceedings2003/bmr.htm

Caravetta, G.J., J.H. Cherney, and K.D. Johnson. 1990. Within-row spacing influences on diverse sorghum genotypes. Agronomy Journal 82:206-210.

Ceres. 2009. High biomass sorghum. Accessed at:

http://www.bladeenergy.com/Bladepdf/Blade_ProductGuide2010.pdf

Cherney, J.H., K.D. Johnson, J.J. Volenec, E.J. Kladivko, and D.K. Greene. 1990. Evaluation of potential herbaceous biomass crops on marginal crop lands: 1) Agronomic potential, final report 1985-1989. ORNL/Sub/85-27412/5\&P1. Oak Ridge National Laboratory, Oak Ridge, TN. Available at: http://bioenergyornl.gov

Cotton.org. 2010. Cotton: From field to fabric, harvesting \& seed cotton storage. Accessed at: http://www.cotton.org/pubs/cottoncounts/fieldtofabric/harvest.cfm

D-8 Secretariat. 2008. Nigeria's first biorefinery to be constructed. Agriculture Energy Industry News 29 April 2008, D-8 Organization for Economic Cooperation. Accessed at:

http://www.developing8.org/2008/04/29/nigerias-first-biofuel-refinery-to-be-constructed/

FAO. 1994. Breeding and cultivation of sweet sorghum. Ch 2 IN Lu Nan, Gustavo Best, and Carlos Coelho de Carvalho Neto (eds.): Integrated energy systems in China - The cold northeastern region experience. Food and Agriculture Organization of the United Nations, Rome. Accessed at: http://www.fao.org/docrep/t4470E/t4470e05.htm\#2.\%20breeding\%20and\%20cultivation\%20of\%20s weet $\% 20$ sorghum

Fannin, Blair. 2009. Texas Agrilife research showcases bioenergy program at media day. AgriLife News, August 14, 2009. Accesses at: http://agnews.tamu.edu/showstory.php?id=1363

Farré, Imma and José María Faci. 2004. Comparative response of maize (Zea mays L.) and sorghum (Sorghum bicolor L Moench) to irrigation deficit in a Mediterranean climate. Paper presented at $4^{\text {th }}$ International Crop Science Congress, Brisbane, Australia, 26 September - 1 October 2004. Accessed at: http://www.cropscience.org.au/icsc2004/poster/1/3/2/1240_farreiok.htm

FBAE. 2008. Sweet sorghum: A new smart biofuel crop that ensures food security. 19 May 2008. Foundation for Biotechnology Awareness and Education. Accessed at: fbae.org/2009/FBAE/website/biofuels sweet-sorghum.html

Grassi, Guiliano. No date. Low cost production of bioethanol from sweet sorghum. European Biomass Industry Association. Accessed at:

http://www.sseassociation.org/SS\%20Publications/eubia/giulianograssi\%20greenpower\%20conference . .pdf 
Hernandez, Eloisa E. 2009. Six promising sweet sorghum hybrids identified. BAR Chronicle 10(1) (January 2009). Accessed at: http://www.bar.gov.ph/barchronicle/2009/jan2009_news1.asp

ICRISAT. 2007. Sweet sorghum: A water saving, bio-energy crop for the Philippines. The International Crops Research Institute for the Semi-Arid Tropics, Patancheru, Andhra Pradesh, India.

ICRISAT. 2009. Sorghum production practices - Area and distribution of sorghum. Accessed at: http://www.icrisat.org/vasat/learning_resources/crops/sorghum/sorghum_prodpractices/html/m2l1/inde $\underline{x . h t m l}$

Johnson, K.D., J.H.Cherney, D.K. Greene, and J.J. Volenec. 1991. Evaluation of switchgrass and sorghum biomass potential, final report 1989-1991. Department of Agronomy, Purdue University, West Lafayette, IN. Available at: http://bioenergyornl.gov

Jørgensen, Uffe and Kirsten Schelde. 2001. Energy crop water and nutrient use efficiency. The International Energy Agency, IEA Bioenergy Task 17, Short Rotation Crops. Accessed at: http://www.p2pays.org/ref/17/16275.pdf

KSUAES\&CES. 1998. Grain sorghum production handbook. C-687. Kansas State University Agricultural Experiment Station and Cooperative Extension Service. Manhattan, KS. Accessed at: http://www.ksre.ksu.edu/library/crpsl2/c687.pdf

Klein, Robert R., John E. Mullet, David R. Jordan, Frederick R. Miller, William R. Rooney, Monica A. Menz, Cleve D. Franks, and Patricia E. Klein. 2008. The effect of tropical sorghum conversion and inbred development on genome diversity as revealed by high-resolution genotyping. The Plant Genome [A Supplement to Crop Science] 48(S1):S12-S26.

Koch, Dave. No date. Sorghums and sudangrass - Management for supplemental and emergency forage. SMRR Info Source. Accessed at: http://www.wyorange.net/Drought/sorghum.html

McCorkle, Dean, Dan Hanselka, Brent Bean, Ted McCollum, Steve Amosson, Stephen Klose, and Mark Waller. 2007. The economic benefits of sorghum silage as an alternative crop. MKT-3557L 06/07. AgriLife Extension, Texas A\&M System.

Monk, R.L., F.R. Miller, and G.G. McBee. 1984. Sorghum improvement for energy production. Biomass 6:145-153.

Msucares.com. 2009. Sorghum production in Mississippi. Accessed at: http://msucares.com/crops/sorghum/descriptions.html

National Sorghum Producers. 2008. Edenspace announces Energy Sorghum $\mathrm{tm}_{\mathrm{m}}$ seed products. Sorghum e-notes, November 6, 2008. Accessed at: http://www.sorghumgrowers.com/Sorghum\%20Notes/2008\%20Sorghum\%20Notes/November\%206, \%202008.pdf

National Sorghum Producers. 2009. 2009 National Sorghum Yield \& Management Contest Results. Accessed at:

http://www.sorghumgrowers.com/Yield\%20Contest/2009\%20Yield\%20Contest\%20Results.pdf 
National Sorghum Producers. No date. Sorghum for ethanol production.

Natural Resources Institute. No date. Sorghum: Post-harvest operations. Food Security Department. Accessed at: http://www.fao.org/inpho/content/compend/text/ch07.htm

New, Leon. 2004. Grain sorghum irrigation. B-6152, 6-04. Texas Cooperative Extension Amarillo, TX. Accessed at:

http://txspace.tamu.edu/bitstream/handle/1969.1/87197/pdf_1843.pdf?sequence=1

News.mongabay.com. 2008. Renergie receives $\$ 1.5$ million grant for sweet sorghum ethanol production. 8 March 2008. Accessed at: http://news.mongabay.com/bioenergy/2008/03/renergiereceives-15-million-grant-for.html

Ngouajio, Mathieu, J. Breinling, R. Goldy, M. Hausbeck, G. McManus, D. Mutch,S. Snapp, D. Warncke, and B. Zandstra. No date. Cropping systems to improve vegetable production under short crop rotation. GR02-057, MSU Dept. of Horticulture. Accessed at:

http://fieldcrop.msu.edu/documents/GR02-057.pdf

Norwood, C.A., A.J. Schlegel, D.W. Morishita, and R.E. Gwin. 1990. Cropping system and tillage effects on available soil water and yield of grain sorghum and winter wheat. Journal of Production Agriculture 3(3):356-362.

Owens, Vance. 2009. The Regional Feedstock Partnership: Herbaceous energy crops and CRP land for biomass production across environmental gradients. Biomass 2009, 17-18 March 2009, Washington, DC. Accessed at: http://www1.eere.energy.gov/biomass/pdfs/Biomass_2009_Sustainabiliy_III_Owens.pdf

Pari, Luigi, Giuliano Grassi, and Stefano Capaccioli. 2008. State of the art: Harvesting, storage and logistic of the sweet sorghum. pp. 174-177 in Proceedings of the $16^{\text {th }}$ European Biomass Conference \& Exhibition 2-6 June 2008, Valencia, Spain. Accessed at:

http://web.etaflorence.it/uploads/media/OD4.5_paper_01.pdf

Pederson, Jeff and Jeff Dahlberg. 2008. Feedstock development. International Conference on sorghum for biofuels, 19-22 August 2008, Houston, TX. Accessed at:

http://www.ars.usda.gov/meetings/Sorghum/Final\%20Report\%20on\%20the\%20international\%20Conf erence.pdf

Qingshan, Lu and Jeffrey Dahlberg. 2001. Chinese sorghum genetic resources. Economic Botany 55(3):401-425.

Reddy, Belum VS, A. Ashok Kumar, and William D. Bar. No date. Overview of sorghum breeding at ICRISAT: Opportunities and constraints. Accessed at:

http://www.ifad.org/events/sorghum/b/Reddy.pdf

Reddy, Belum VS, S. Ramesh, P. Sanjana Reddy, B. Ramaiah, P.M. Salimath, and Rajashekar Kachapur. 2005. Sweet sorghum - A potential alternative raw material for bio-ethanol and bioenergy. Sorghum and Millets Newsletter 46:79-96.

Reddy, Belem VS, HC Sharma, RP Thakur, S Ramesh, Fred Rattunde, and Mary Mgonja. 2006. Sorghum hybrid parents research at ICRIAT - Strategies, status, and impacts. SAT ejournal | 
ejournal.icrisat.org 2(1):1-24.

Reddy, Belum VS, A. Ashok Kumar, and S. Ramesh. 2007. Sweet sorghum: A water saving bioenergy crop. International Conference on Linkages between Energy and Water Management for Agriculture in Developing Countries, 29-30 January 2007, IWMI, ICRISAT Campus, Hyderabad, India. Accessed at: http://www.icrisat.org/Biopower/BVSReddyetalSweetSorghumWatersavingJan2007.pdf

Reddy, Belum V.S., William D. Dar, P. Parthasarathy Rao, P. Srinivasa Rao, A. Ashok Kumar, and P. Sanjana Reddy. 2008. Sweet sorghum as a bioethanol feedstock: Challenges and opportunities. International Conference on Sorghum for Biofuel, 19-22 August 2008, Houston, TX. Accessed at: http://www.ars.usda.gov/meetings/Sorghum/presentations/Reddy.pdf

Roth, Gregory W. 1995. Forage sorghum. Agronomy Facts 48.Penn State, College of Agricultural Sciences, cooperative Extension. Accessed at: http://cropsoil.psu.edu/Extension/Facts/agfact48.pdf

Schill, Susanne Retka. 2007. Tall Texas sorghum. Ethanol Producer Magazine, November 2007. Accessed at: $\underline{w w w . e t h a n o l p r o d u c e r . c o m / a r t i c l e-p r i n t . j s p ? a r t i c l e ~ i d=3424 ~}$

Singh BR and DP Singh. 1995. Agronomic and physiological responses of sorghum, maize and pearl millet to irrigation. Field Crops Research 42:57-67.

Soltani, A. and A. Almodares. 1994. Evaluation of the investments in sugar beet and sweet sorghum production. National Convention of Sugar production from Agriculture products, 13-16 March 1994, Shahid Chamran University, Ahwaz, Iran.

Teutsch, Chris. 2006. Warm-season annual grasses for summer forage. Publication 418-004. Communication and Marketing, College of Agriculture and Life Sciences, Virginia Polytechnic Institute and State University. Accessed at: http://pubs.ext.vt.edu/418/418-004/418-004.pdf

Tew, Thomas L., Robert M. Cobill, and Edward P. Richard, Jr. 2008. Evaluation of sweet sorghum and sorghum x sudangrass hybrids as feedstocks for ethanol production. Bioenergy Research 1:147152

Thomasson, J. A., B. E. Hartley, J. D. Gibson, R. Sui, S. W. Searcy. 2009. Characteristics of HighBiomass Sorghum as a Biofuel. Paper number 090015. ASABE Annual International Meeting, June 21 - June 24, 2009, Reno Nevada.

Viator, Ryan P., Edward P. Richard, Jr., Donnie D. Garrison, Edwis O. Dufrene, Jr., and Thomas L. Tew. 2005. Sugarcane cultivar yield response to planting date. Journal American Society Sugar Cane Technologies 25(2005):78-87.

Wikipedia. 2010. Cotton module builder. Accessed at: http://en.wikipedia.org/wiki/Cotton_module_builder 